Maurer School of Law: Indiana University

Digital Repository@Maurer Law

Indiana Law Journal

Volume 84 | Issue 2

Article 1

Spring 2009

\title{
The Lost Meaning of the Jury Trial Right
}

Laura I. Appleman

Willamette University, appleman@willamette.edu

Follow this and additional works at: https://www.repository.law.indiana.edu/ilj

Part of the Courts Commons

\section{Recommended Citation}

Appleman, Laura I. (2009) "The Lost Meaning of the Jury Trial Right," Indiana Law Journal: Vol. 84 : Iss. 2 , Article 1.

Available at: https://www.repository.law.indiana.edu/ilj/vol84/iss2/1

This Article is brought to you for free and open access by the Law School Journals at Digital Repository @ Maurer Law. It has been accepted for inclusion in Indiana Law Journal by an authorized editor of Digital Repository @ Maurer Law. For more information, please contact rvaughan@indiana.edu.

\section{$\Psi$}

JEROME HALL LAW LIBRARY

INDIANA UNIVERSITY

Maurer School of Law
Bloomington 


\title{
The Lost Meaning of the Jury Trial Right ${ }^{\dagger}$
}

\author{
LAURA I APPLEMAN"
}

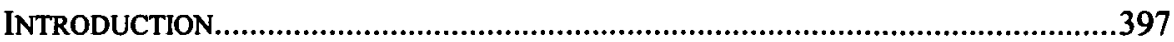

I. THE SUPREME COURT AND THE HISTORICAL JURY RIGHT ................................400

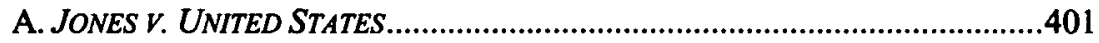

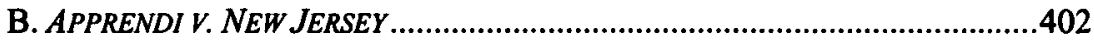

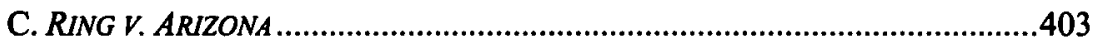

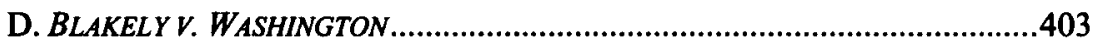

II. THE EARLY HISTORY OF THE JURY TRIAL RIGHT ..........................................405

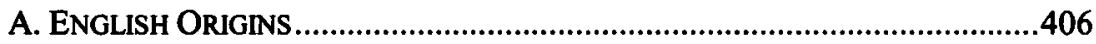

B. COMMUNITY AND JURIES BEFORE THE REVOLUTION...............................408

III. FROM LOCAL POWER TO THE COLLECTIVE JURY TRIAL RIGHT .......................414

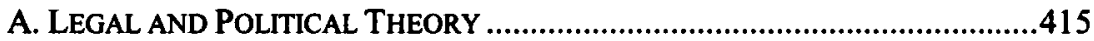

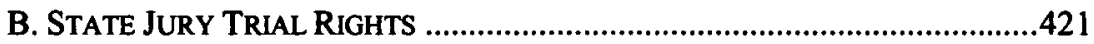

C. CONSTITUTIONAL CODIFICATION OF THE JURY TRIAL..............................426

D. EROSION AND DECLINE .............................................................439

IV. APPLYING THE COLLECTIVE JURY RIGHT TO THE BENCH TRIAL ......................440

A. THE POWER SHIFT TO THE TRIAL JUDGE .............................................443

B. BENCH TRIALS AS SURREPTITIOUS PLEA DEALS ...................................444

C. THE BENCH TRIAL ACQUITTAL GAP ...................................................444

D. DEMOCRATIC DELIBERATION AND IMPROVED DECISION MAKING............444

E. BENCH TRIALS AND COMPLEX CRIMINAL CASES ...................................445

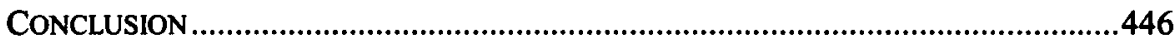

\section{INTRODUCTION}

Apprendi v. New Jersey ${ }^{1}$ and Blakely $v$. Washington ${ }^{2}$ instigated a tremendous revolution in criminal procedure. ${ }^{3}$ These "number 10 earthquake[s]" have caused a

$†$ Copyright (C) 2008 Laura I Appleman.

* Assistant Professor of Law, Willamette University. J.D., Yale University; B.A., M.A., English, University of Pennsylvania. Special thanks to Stephanos Bibas, Jennifer Collins, Rose Cuison-Villazor, David Friedman, Lisa Lewis, Tom Lininger, William Nelson, Hari Osofsky, Alice Ristroph, Nick Rosenkranz, Jenia Turner, and Norman Williams, as well as the participants in the George Washington Junior Criminal Professor Conference, the Hofstra Faculty Colloquium, the SMU Colloquium on Law \& Citizenship, and the Willamette Valley Junior Faculty Workshop. Thanks also to Willamette for its research support.

1. 530 U.S. $466(2000)$ (declaring unconstitutional a New Jersey hate-crime statute enabling a sentencing judge to impose a sentence beyond the statutory maximum for various crimes).

2. 542 U.S. 296 (2004) (reaffirming a criminal offender's right to a jury's determination of facts that allow an increase in the maximum sentence).

3. In the Apprendi-Blakely line of cases, the Court held that the jury must find all facts that may be considered to increase a criminal offender's punishment, focusing on the role of the community as long-standing moral arbiters. See Blakely, 542 U.S. 296; Apprendi, 530 U.S. 466.

4. Charles Lane, Supreme Court to Consider Federal Sentencing Guidelines, WASH. POST, 
massive rethinking of sentencing law and policy. Until now, however, there has been only meager historical and scholarly support for the keystone of the Court's sentencing decisions: the scope, meaning, and provenance of the jury trial right. ${ }^{5}$ In response, I provide the missing historical and constitutional justification for the Supreme Court's fidelity to the jury. In doing so, I will show that the original jury trial right was a community right, not the individual right we currently envision.

Part of the difficulty the Court has faced with its championing of jury rights is due to the Constitution's two criminal jury clauses, each seemingly addressing a different right. The first, in the Constitution proper, reads like a collective right, or a right of the people: "The Trial of all Crimes, except in Cases of Impeachment, shall be by Jury; and such Trial shall be held in the State where the said Crimes shall have been committed ...." The second, in the Bill of Rights, reads like a right of the accused: "In all criminal prosecutions, the accused shall enjoy the right to a speedy and public trial, by an impartial jury of the State and district wherein the crime shall have been committed, which district shall have been previously ascertained by law ...."

Until quite recently, the Court consistently emphasized the second version of the jury trial right, which focuses on the individual. Modern scholarship is gradually rediscovering the first ${ }^{8}$ with Akhil Amar in particular emphasizing that the right has a collective dimension. ${ }^{9}$

I go further still, claiming that even the Sixth Amendment jury trial right, which sounds grammatically like a right of the accused, is actually a restatement of the collective right in Article III. My historical research confirms that the jury trial right in Article III was strictly a collective right, as its grammar suggests. My central claim is that nothing in the Sixth Amendment was meant to change this historical understanding and confer an individual right on defendants. Our understanding of the jury trial right as an extension of the defendant's individual liberties came later and with a much different gloss.

These latter-day interpretations have shifted the meaning of the jury trial right well away from its original meaning. My reading of the historical jury trial right has many important implications, including, if taken to the extreme, the elimination of guilty pleas, bench trials, jury trial waivers, and even peremptory challenges.

Jan. 3, 2004, at A10 (quoting Justice Sandra Day O'Connor).

5. This lack of historical support has been specifically noted by Stephanos Bibas. See Stephanos Bibas, Originalism and Formalism in Criminal Procedure: The Triumph of Justice Scalia, the Unlikely Friend of Criminal Defendants?, 94 GEO. L.J. 183, 185 (2005).

6. U.S. CONST. art. III, $\S 2$.

7. U.S. ConsT. amend. VI.

8. See, e.g., Bibas, supra note 5, at 196-97 (arguing that Article III of the Constitution was meant to protect the right of the People to administer justice, and not the right of the individual that may be waived); Steven Engel, The Public's Vicinage Right: $A$ Constitutional Argument, 75 N.Y.U. L. REV. 1658, 1705-06 (2000) (arguing that the public has a constitutional right to locally administer justice and adjudicate criminal trials); Nicholas Quinn Rosenkranz, Condorcet and the Constitution: A Response to the Law of Other States, 59 STAN. L. REV. 1281, 1298 (2007) (citing Akhil R. Amar's conclusion that the jury was intended to be a local institution). See generally AKHIL REED AMAR, THE BILL OF RIGHTS: CREATION AND RECONSTRUCTION (1998) (promoting the idea that the Bill of Rights and Constitution are carefully structured with specific rights, including the right to a jury trial, designed to educate and empower the popular majority).

9. See generally AMAR, supra note 8 . 
We have consistently viewed the right to the jury trial through the wrong lens, mistakenly ascribing it to the accused. Much of the original understanding of the jury trial right has been lost due to our current focus on the raft of individual liberties granted to a defendant. But the jury trial right, for the British colonies and later the confederation of states, was primarily about the fledgling American community's ability to judge its own people and pronounce their punishment.

These ideas were widespread and influential at the time the Constitution was drafted and ratified, and provided a valuable context for understanding the right to a jury trial. The concept of the collective people's right to a jury trial can be found in three major contemporary sources: the influential theoretical works and law treatises of Edward Coke, Matthew Hale, Cesare Beccaria, William Blackstone, and other seventeenth- and eighteenth-century authors who discussed the right to a jury trial; ${ }^{10}$ historical accounts of punishment and sentencing in colonial America; ${ }^{11}$ and the Founding era writings and speeches of American pamphleteers, essayists, statesmen, politicians, and citizens. ${ }^{12}$ Based on these sources, I contend that an eighteenth-century audience would have genuinely understood the right to a jury trial to be a collective right.

The collective right to a jury trial-allowing the local community to hand down a public punishment and then restore the offender back to his place in society-has great import for our current regime of criminal punishment and sentencing. If we are now relying on jury trial origins to support the Court's sentencing reforms, we must fully understand the contours and ramifications of the historical jury right to chart our future path.

In Part I, I discuss the Supreme Court's interpretation of the jury trial right, briefly reviewing the landscape of the Court's recent sentencing reforms. In doing so I show how the Court's failure to distinguish between the collective and individual jury trial right has led to confusion and lack of clarity in the Court's sentencing opinions. I also explain how the Court's continuing interest in the jury trial's constitutional and common-law origins helps demonstrate the continuing importance of the historical meaning of the jury trial right.

I make my positive case in Part II and Part III. In these Parts, I offer a textualhistorical reading of the Sixth Amendment based on seventeenth- and eighteenthcentury legal theory, linguistic usage, and colonial and American Revolutionary practices. In doing so, I conclude that a conception of the jury trial right as the community's right is entirely plausible. I do so by exploring the historical evolution of the right to a jury trial and the community's role in imposing punishment, tracing it from its early beginnings in England through its full fruition in the post-Revolution and Constitution drafting periods.

In Part IV, I briefly explore what the implications of my historical findings on modern criminal procedure might be, focusing specifically on bench trials. I argue that bench trials should be eliminated in light of the historical meaning of the jury trial right. In so doing, I show why eliminating bench trials would not only be a return to original common-law and constitutional meaning, but also a way to improve the criminal justice system.

10. See infra Part III.A.

11. See infra Part III.B.

12. See infra Part III.C. 
There is a reason that the jury was so critical to the founding of this nation. The right of the people to participate in one of the principal functions of a community-the handing down of criminal justice-could only be developed and valued in this uniquely American experiment. As Thomas Jefferson argued in 1781, "the common sense of twelve honest men gives still a better chance of just decision, than the hazard of cross and pile." ${ }^{13}$ Now that we have finally expanded the jury franchise to almost all members of our society—all genders, all races, all classes-why do we choose to curtail it?

\section{THE SUPREME COURT AND THE HISTORICAL JURY RIGHT}

The Supreme Court has only recently focused its sights on the history of the jury trial right as a way to bolster its Sixth Amendment sentencing jurisprudence. In the Apprendi-Blakely line of cases, the Court relied heavily on the historical role of the criminal jury to support its contention that only a jury may find the facts that increase an offender's punishment above the maximum. ${ }^{14}$ The Court's failure to distinguish between the collective and individual jury trial right, however, has sowed considerable confusion.

A review of the Court's recent sentencing decisions illustrates the conflict between the two different ways to understand the jury trial right. On the one side, championed by Justices Stevens, Souter, and O'Connor, is the view of the jury trial right as an individual right, part of the due process afforded defendants in criminal offenses. ${ }^{15} \mathrm{On}$ the other side, championed by Justices Scalia and Thomas, is the view of the jury trial right as a community right. ${ }^{16}$ Although never fully articulated as such, the Court's attempt to simultaneously ride both horses has complicated the jury trial right's actual meaning, leaving uncertainty in its wake. Combined with the "shaky foundations"17 of the Court's history of the jury, this conflict weakens the arguments for a renewed fidelity to the jury's role in criminal sentencing and points to the need for a better understanding of the jury trial right's heritage.

Below I briefly examine the Court's use of the jury trial right in sentencing, pointing out where its historical evidence has proved thin as well as noting where the two conflicting conceptions of the jury trial right have muddied the waters of its jurisprudence.

13. Thomas Jefferson, Query XIV: Laws, in THE PORTABLE ThOMAS JeFFERson 177 (Merrill D. Peterson ed., 1977).

14. See Blakely v. Washington, 542 U.S. 296 (2004); Apprendi v. New Jersey, 530 U.S. $466(2000)$.

15. See Blakely, 542 U.S. at 318-19, (O'Connor, J., dissenting); id. at 334-35, 337-38 (Breyer, J., dissenting).

16. See Blakely, 542 U.S. at 301-02, 305-06; Apprendi, 530 U.S. at 499 (Scalia, J., concurring).

17. Bibas, supra note 5, at 195. 


\section{$A$. Jones v. United States}

Jones $v$. United States ${ }^{18}$ was the first sentencing case in which the Court began to rely on the history of the jury to support the jury's more expansive role. One of the chief concerns in Jones was to determine the history and boundaries of the constitutional safeguards for fact-finding procedures, particularly the identity of the fact-finder. ${ }^{19}$ By expounding on the history of criminal sentencing as well as the Framers' concerns over jury rights, the Jones Court underlined the importance of the jury's control over the ultimate verdict. ${ }^{20}$

The Jones Court made its historical interest clear by highlighting the ancient tension between the jury and judicial powers. ${ }^{21}$ Jones provided three historical examples of why the founders so cherished the right to a jury trial. First, England had a long tradition of indirectly checking the severity of sentences through the jury's power to mitigate by acquittals and purposeful verdicts of lesser-included offenses; the founders carried this tradition with them. ${ }^{22}$ Second, the Crown's attempt to confine jury determinations in libel cases to findings of fact dramatically failed, and the colonists carefully noted this lesson. ${ }^{23}$ Finally, England's decision to bar the jury trial when defining new statutory offenses led to the protest, in the Declaration of Independence, against the general deprivation of a jury trial-illustrating the importance of the jury trial in the minds of the Framers. ${ }^{24}$ As the Court commented, " $[t]$ here was apparently some accepted understanding at the time that the finding of facts was simply too sacred a jury prerogative to be trifled with in prosecution for such a significant and traditional offense in the common-law courts."25

A large part of the Jones Court's reasoning was to ensure that the jury's role in criminal justice proceedings would not wither from its traditional job of determining guilt to the function of "low-level gatekeeping."26 The Court thus signaled that any future "relative diminution of the jury's significance" would raise Sixth Amendment concerns. ${ }^{27}$ The Jones Court's steadfast championing of the jury trial right as a community right, based on the history of the jury, laid the groundwork for the Court's even stronger reliance on historical sources in its future sentencing cases, and framed the issue as one of constitutional importance.

The Jones Court, however, muddied its message of the jury trial right as a key community right by simultaneously indicating that the jury trial right was an individual one. On one hand, the Court argued that any "diminishment of the jury's significance" would generally "raise a genuine Sixth Amendment issue,"28 and imagined the jury as a collective voice. On the other, the Court still assumed the jury trial right was one

18. 526 U.S. 227 (1999).

19. See id. at 243 n.6.

20. See id. at $244-47$.

21. See id. at 244.

22. Id. at 245 .

23. See id. at 246-47.

24. See id. at 245-47.

25. Id. at 247.

26. Id. at 244 .

27. Id. at 248 .

28. Id. 
"belonging" to the accused. ${ }^{29}$ This switching between the individual and collective articulations of the jury trial right somewhat undercut the thrust of the Court's historical support for its sentencing reform.

\section{B. Apprendi v. New Jersey}

A year later, in Apprendi v. New Jersey, ${ }^{30}$ the Court continued to rediscover the historical jury trial right. The Apprendi Court relied on the historical foundations of the common law as a basis for holding that the jury had the right to find each and every factual element of a crime on the basis of proof beyond a reasonable doubt. ${ }^{31}$ However, the Court once again failed to distinguish between the collective and an individual right in its discussions of the jury's role.

In Apprendi, as in Jones, the Court returned to the communitarian view of the jury trial as a means of ensuring that the state did not overreach its powers. The "twelve of [the defendant's] equals and neighbours," 32 part of the offender's local community, were characterized as "the great bulwark of [our] civil and political liberties."33 Thus the Court recognized the pivotal role of the local community as participants in the criminal jury trial - if there was no community, the "great bulwark" could not exist.

The Court argued that, historically, the community's punishment decisions prevented the state or government from arbitrarily imposing punishment that did not meet with the community's approval. However, the majority's reliance on nineteenthcentury treatises ${ }^{34}$ and Justice Thomas's reliance on mid-to-late-nineteenth-century nonconstitutional cases ${ }^{35}$ as historical support left it on somewhat shaky grounds. As Stephanos Bibas has pointed out, "[t]hese sources are very weak evidence of the original understanding of the Constitution." ${ }^{36}$ The Court simply did not provide a strong historical basis for its assertions-something that I attempt to redress. ${ }^{37}$

Moreover, the Court again attempted to play both sides of the arena by invoking two competing ideas of the jury trial right. The Apprendi majority first staked out the individual right, stating that the "starkly presented"38 question was whether a defendant had the constitutional right to have a jury find each and every factual element of a crime. ${ }^{39}$ But the opinion then rapidly turned to an espousal of the collective right,

29. See id. at $251 \mathrm{n} .11$.

30. 530 U.S. $466(2000)$.

31. See id. at 476 .

32. Id. at 477 (quoting 4 WILlIAM BlaCKSTONE, COMMENTARIES ON THE LAWS OF ENGLAND $343(1769))$.

33. Id. (quoting 2 JOSEPH STORY, COMMENTARIES ON THE CONSTITUTION OF THE UNITED STATES 540-41(4th ed. 1873)).

34. The majority relied upon treatises written by such prominent nineteenth- and twentiethcentury figures as Justice Story, John F. Archbold, and J. Bishop, among others. See id. at 47678,482 n.9, 490 n. 15 .

35. See id. at 500-23 (Thomas, J., concurring).

36. Bibas, supra note 5 , at 196.

37. Bibas notes that "[t]he history of these [jury trial] clauses is no clearer" than what limited sources the Court provided. Id. I take up that challenge and provide a full history of the jury trial clauses in the Constitution and Bill of Rights below.

38. Apprendi, 530 U.S. at 476 .

39. Id. 
explaining the Court's conception of the jury as the final arbiter of the facts determining an offender's punishment, and emphasizing the importance of the community's role in measuring levels of blameworthiness. ${ }^{40}$ Stated differently, once the Court addressed the history of the jury trial right, its language and phrasing quickly switched to a community right.

In contrast, Justice Scalia's Apprendi concurrence focused primarily on the community jury trial right. Although noting that the language of the Sixth Amendment focused on the accused, Scalia pointed out that the founders of the American Republic had no intentions of leaving criminal punishment to the government. ${ }^{41}$ Thus the jurytrial guarantee was, historically, a fundamental preservation of the community's rights, because "all the facts which must exist in order to subject the defendant to a legally prescribed punishment must be found by the jury." ${ }^{42}$ Scalia's focus on the collective jury right is a critical one, and, as I will show, one supported by the historical record.

\section{Ring v. Arizona}

Following Apprendi, the Court's sentencing opinions relied more strongly upon an understanding of the jury trial right as a community right. In Ring $v$. Arizona, ${ }^{43}$ the Court held that if a sentencing fact critically affected an offender's punishment, it was impermissible for the "trial judge, sitting alone," absence of "aggravating factors" 45 required by a state to increase a death sentence. Once again, the Court relied on the ancient prerogatives of the jury right to support the holding. ${ }^{46}$

Drawing heavily on Justice Stevens's previous dissent in Walton $v$. Arizona ${ }^{47}$ the Ring Court explored the nuances of the criminal jury trial during the Founding era. The Court asserted that the eighteenth-century jury had an unquestionable right to decide not only the facts but also the punishment in capital cases: "[a]s fact-finder, the jury had the power to determine not only whether the defendant was guilty of homicide but also the degree of the offense. ${ }^{, 48}$ By emphasizing that the historical role of the jury as arbiter of punishment was framed into the Bill of Rights, Ring nodded to the community's job determining punishment for offenders in capital crimes.

D. Blakely v. Washington

The Court's belief in the importance of the historical role of the jury came to full fruition in Blakely $v$. Washington. ${ }^{49}$ In holding that a court can only sentence a

40. Id. at $477-84$.

41. Id. at 498 (Scalia, J., concurring).

42. Id. at 499 (emphasis in original).

43. 536 U.S. 584 (2002).

44. Id. at 588 .

45. Id.

46. See id. at 599,607 .

47. 497 U.S. 639 (1990).

48. Ring, 536 U.S. at 599 (Stevens, J., dissenting) (quoting Walton v. Arizona, 497 U.S. $639,710-11(1990))$.

49. 542 U.S. $296(2004)$. 
defendant on facts found by the jury beyond a reasonable doubt or admitted by the defendant himself, ${ }^{50}$ the Blakely Court gave strong support to the idea that the community must have the final word on criminal punishment.

The Blakely Court argued that its rule was supported by the long American history of common-law criminal justice. Quoting Blackstone, the Court observed both that the "'truth of every accusation' against a defendant 'should afterwards be confirmed by the unanimous suffrage of twelve of his equals and neighbours",51 and that "an accusation which lacks any particular fact which the law makes essential to the punishment is ... no accusation within the requirements of the common law, and it is no accusation in reason." 52

The community's role in the jury trial, the Court explained, was a key reservation of the community's power in the structuring of our government: "[j]ust as suffrage ensures the people's ultimate control in the legislative and executive branches, [a] jury trial is meant to ensure their control in the judiciary." ${ }^{\circ 3}$ By relying on the jury's function as the public's representative and as the primary provider of community-based punishment to support its holding, Blakely endorsed a collective understanding of the jury trial right.

The Court placed such importance on the jury's role during sentencing in part because of its recent-and related-emphasis on the community's traditional role in determining moral blameworthiness. ${ }^{54}$ Blakely contended that the liberal, democratic decision making vested in the jury's determination of blameworthiness relied on the community's role in linking punishment to the crime committed, so that the offender would feel more responsibility for her actions. ${ }^{55}$

This tie between community-based retribution and the jury's role in finding all facts relevant to punishment-a theme that runs through many of the Court's modern sentencing opinions--was supported almost entirely by historical sources, including Blackstone and a variety of Ratification-era documents. ${ }^{56}$ Again, however, the Court also relied on the same nineteenth-century treatises that imperfectly supported Apprendi. ${ }^{57}$ Only a return to the original sources can provide true support for the Court's sentencing reforms, both current and future.

In sum, teasing out the meaning of the jury trial right, and being able to distinguish between the collective and an individual jury right, is crucial to the Court's new direction in sentencing. Although the historical record provided by the Court has its gaps, the complete history of the jury trial right, as I will show, supports the Court's sentencing jurisprudence and further strengthens the call for a strong jury role.

50. See id. at 313 (citation omitted).

51. Id. at 301 .

52. Id.

53. Id. at 306.

54. See generally id.; Ring v. Arizona, 536 U.S. 584 (2002); Apprendi v. New Jersey, 530 U.S. 466 (2000); Jones v. United States, 526 U.S. 227 (1999); Walton v. Arizona, 497 U.S. 639 (1990).

55. See Blakely, 542 U.S. at 309.

56. See id. at $301-02,306$.

57. See id. at 302; see also id. at 342-43 (Breyer, J., dissenting). 


\section{THE EARLY HISTORY OF THE JURY TRIAL RIGHT}

Although much has been written about the origins of the jury trial right, it has been largely focused on the rights of the defendant. ${ }^{58}$ The existing scholarship on the community's jury trial right is still incomplete.

Historians studying the right to a jury trial in seventeenth- and eighteenth-century America have typically focused on how the right passed over from England and was incorporated into the Constitution. ${ }^{59}$ In doing so, however, they have largely ignored a critical aspect of the jury trial right: that it was primarily the people's prerogative. The few legal scholars who have analyzed the jury trial right have come closer to its original meaning, agreeing that the jury trial was both local and popular. ${ }^{60}$ Most of these scholars, however, have classified the jury trial as part of the debate over the crystallization of popular representation in government during the writing of the Constitution. ${ }^{61}$

Akhil Amar has briefly touched upon the idea of a collective jury trial right, arguing that the right to a jury trial focused on the local community during the ratification debates due to concerns over popular representation. ${ }^{62}$ I expand on this assertion by illustrating that the right to a jury trial, particularly in the criminal context, was viewed almost exclusively as the people's right, not as a right of the accused, as demonstrated by the original historical sources.

In the next two Parts, I take the notion of a local and popular jury to the next level. I contend that the much-vaunted right to a jury trial was originally the people's right to a public trial, and this understanding of the jury trial right had great impact on colonial punishment and the debate over trial by jury both before and after the Revolutionary period. In support of my claim, I return to documentary historical sources, and show how the community's right to a jury trial was always an integral part of the common law, continuing to be viewed as such through the War of Independence and the writing of the Constitution.

Although I do not deny that the criminal defendant possessed a small stake in the matter, accounts from contemporary newspapers, legal treatises, and popular writing show that the jury trial right, as handed down from England, was understood as the right to have an offender's crimes tried before the local community. Thus returning to historical origins teaches us that the right to a jury trial is grounded in the community's central role in deciding punishment for criminal offenders and in its ability to determine moral blameworthiness.

By exploring the history of the jury trial right from the colonial beginnings through the Revolutionary period, I hope to deepen our comprehension of not only the role of

58. See Leonard LeVy, Original Intent and the Framers' Constitution 150 (1988). See generally WILLIAM FORSYTH, HISTORY OF TRIAL BY JURY (1971) (describing the origins of the American jury).

59. See, e.g., Welsh S. White, Fact-Finding and the Death Penalty: The Scope of a Capital Defendant's Right to Jury Trial, 65 NOTRE DAME L. REV. 1, 2-3 (1989) (discussing historical antecedents of the right to a jury trial); Charles W. Wolfram, The Constitutional History of the Seventh Amendment, 57 MINN. L. REv. 639, 640-49 (1973).

60. See, e.g., AMAR, supra note 8, at 88.

61. See id. at 104.

62. See id. at 11. 
the jury in the founding of the nation, but also the role of the community and the people in deciding punishment for local offenders. To be true to our origins and the true meaning of the jury trial right, we must return to historical sources.

\section{A. English Origins}

The origins of the jury - and its intertwinement with the community-stretch far back into the Anglo-American past. Although jury-based trials existed in the twelfth and thirteenth centuries, they were vastly different from our model of a jury trial today. ${ }^{63}$ Drawn from the immediate neighborhood where the crime occurred, the jurors were chosen for their knowledge of the crime or their ability to find out. ${ }^{64}$ In other words, the jurors were to make inquiries, collect testimony, weigh the evidence, and state the verdict ${ }^{65}$ - a far cry from the role played by juries today.

As the "static populace and forms of communal agricultural organization" began to dissolve in the mid-fourteenth century, jurors lost their close proximity to the facts of the cases before them, thus losing their ability to investigate the cases themselves. ${ }^{66}$ The community-based aspect of the jury trial, however, remained the same, despite the more passive role jurors now played in determining an offender's guilt. ${ }^{67}$

The jury trial also played a significant part in the English Bill of Rights, promulgated in 1689 by the House of Lords and Commons against the reign of James the Second. ${ }^{68}$ Enumerated ninth on the list of complaints was the Crown's habit of allowing "partial, corrupt, and unqualified persons [to be] returned and served on juries in trial . . .." In response, Parliament demanded that "jurors ought to be duly impaneled and returned, and jurors which pass upon men in trials for high treason ought to be freeholders."70

Notably, however, the individual rights mentioned in the document-which did not include the jury trial right-were separately listed in another clause. ${ }^{71}$ Thus in one of its earliest forms, the jury trial right was envisioned as a local one, concerned with fair and qualified jurors to best represent the community, not the individual.

It was the eighteenth century, however, when some of the "most fundamental attributes of modern Anglo-American criminal procedure",72 arose, including the

63. See John H. Langbein, The Origins of AdVersary Criminal Trial 64 (2003).

64. See id.

65. See id.

66. Id.

67. See id.

68. See An Act Declaring the Rights and Liberties of the Subject and Settling the Succession of the Crown (Bill of Rights), 1689, 1 W. \& M., c. 2, § 7 (Eng.), available at http://avalon.law.yale.edu/17th_century/england.asp.

69. Id.

70. Id.

71. "That excessive bail ought not to be required, nor excessive fines imposed; nor cruel and unusual punishments inflicted." Id.

72. John H. Langbein, Shaping the Eighteenth-Century Criminal Trial: A View from the Ryder Sources, 50 U. CHI. L. REv. 1, 2 (1983). Langbein notes that the sources for any history of the eighteenth-century criminal trial are "suspect," "scarce," and "unsystematic," as "the contemporary press contains relatively little in the way of trial reporting." Id. at 4. 
relationship between the judge and the jury. Of course, eighteenth-century criminal trials in the Old Bailey Court were significantly different than those of today. ${ }^{73}$ Jury trials were conducted extremely rapidly, with judges often hearing between twelve and twenty felony cases a day, and it was not uncommon for juries to render verdicts "at the bar." $" 74$

Despite these differences, some key aspects survive in today's juries. "Twelveman juries" were commonplace by 1750 , and the men drawn resided in the same venue in which the offense occurred. ${ }^{75}$ Moreover, even the super-efficient retributive justice of eighteenth-century England had its aspects of compassion and restorative justice. In his groundbreaking work about the Ryder trials, John Langbein discusses one trial where, although the jurors convicted a man for robbery, they begged the judge to intercede for a pardon for him, since destitution had led him to the crime. ${ }^{76}$ This was no isolated incident, as Langbein notes that a number of entries in the judge's diary dealt with reprieve and pardon matters. ${ }^{77}$

One other essential aspect of the Old Bailey criminal jury trial was deciding the punishment. Only a few eighteenth-century trials actually were concerned with dividing guilt from innocence; instead, "[t]o the extent that trial had a function in such cases beyond formalizing the inevitable conclusion of guilt, it was to decide the sanction."78 The jury's ability to "downcharge" an offense ${ }^{79}$ gave them great power over the social and psychological ramifications of crime.

Additionally, the Murder Act of 1752 added a very public aspect to the jury's role in punishment, as the Act stipulated that the sentence must be pronounced in open court immediately after the conviction, to "impress a just Horror in the Mind of the Offender, and on the minds of such as shall be present, of the heinous Crime of Murder." ${ }^{80}$ Although the judge pronounced the sentence, it was the jury's role as the public moral arbiter that gained prominence.

In other words, the primary role of the jury in British criminal trials was to determine the defendant's level of moral culpability, to sanction the offender, to restore the victim to his or her original state, and to repair the community by publicly denouncing the crime and the criminal.

It is these particular aspects of criminal jury trials - the size, the vicinage, the aspects of compassion or restorative justice, and role of moral arbiter-that made their way across the ocean to the British colonies. All of these would become imperative to the ideals of American community justice.

73. John H. Langbein, Understanding the Short History of Plea Bargaining, 13 LAW \& SOC'Y REV. 261, 262 (1979).

74. Id. at 262-63.

75. Langbein, supra note 72 , at 15.

76. See id. at 21.

77. See id.

78. Id. at 41 .

79. Id.

80. Id. at 46 . 


\section{B. Community and Juries Before the Revolution}

The colonials did not import the common law unadulterated from the mother country. ${ }^{81}$ Instead, in creating their new legal order they drew on English local and customary law, the body of law most familiar to them, creating "a layman's version of English legal institutions." ${ }^{\text {"2 }}$ The colonial community played a critical role in helping shape the American version of the law, both informally and by using the local jury to adjudicate criminal offenses. As I will show, the jury trial was indistinguishable from the community's role in expressing a form of restorative, retributive justice.

The impact of the role of the community in colonial legal history has not been fully realized. To help bridge that gap, I will explain how the role of the local, so vital to determinations of colonial justice, was translated and formalized into the petit jury. To best understand the jury trial right, we must understand how the local community mediated justice in the early modern colonies.

Colonial justice and jury trials varied widely. The several colonies had substantial differences in their "social arrangements, populations, ideologies, institutional developments, and economic organization." ${ }^{83}$ This was often true within colonies as well. ${ }^{84}$ Nonetheless, there were enough similarities among the types of criminal justice meted out in the British colonies that some amount of generalization is permissible.

As William Nelson has shown, the role of the jury as decider of the law as well as the facts "tells us much about pre-Revolutionary law and society." 85 Juries guided the public trial and punishments of offenders, leaving courts with such minor tasks as delivering jury instructions or deciding pleas in abatement. ${ }^{86}$ The jury was viewed as a means of controlling the discretion of judges and curtailing their authority. ${ }^{87}$

As a symbol and a tool of popular power, the petit jury represented the vox populi, and was intimately tied to the local community. ${ }^{88}$ In many villages, the institutions were one and the same. Both grand and petit juries played a central role in mediating conflicts of interest between local interests and the governing authorities. ${ }^{89}$ Ultimately, "the right to trial by jury was never questioned during the pre-Revolutionary period, and few such cases went to trial without jury." 90 Significantly, the right to trial by jury was understood as the people's right.

81. See Kermit L. Hall, Paul Finkelman \& James W. Ely, American Legal History 23 (1996).

82. Daniel J. Boorstin, The Americans: The Colonial Experience 27 (1958).

83. Douglas Greenberg, Crime, Law Enforcement, and Social Control in Colonial America, 26 AM. J. LEGAL HIST. 293, 296 (1982).

84. See id.

85. William E. Nelson, AMERICANIZATION OF THE COMMON LAW: THE IMPACT OF LEGAL ChaNGe ON MASSACHUSETTS SOCIETY, 1760-1830, at 3 (1975).

86. See id. at 20.

87. See id.

88. See id. at 21.

89. See J. R. Pole, Reflections on American Law and the American Revolution, 50 WM. \& MARY Q., 123, 126 (1993); see also Kevin Washburn, Restoring the Grand Jury, 76 FORDHAM L. REV., 2333, 2387 (2008) (discussing grand jury's role in reflecting community's voice).

90. Nelson, supra note 85 , at 21 ; see also PETER C. HofFER, LAW AND PEOPLE IN COLONIAL AMERICA 119 (1998). But see Eli Frank, Trying Criminal Cases Without Juries in Maryland, 17 VA. L. REV. 253, 254 (1931) (arguing that right to a trial without jury existed since Maryland's 
In all of the British colonies, jury trials and the law reinscribed the mores of the community. This was necessary, of course, in a system that allowed juries to decide both the law and the facts; law "had to be derived from widely accepted moral principles or customary norms that had become rooted among those portions of the community which might be called upon to enforce the norms as jurors."

The jury's authority over the law meant that the local community was able to both create and control the content of the colony's substantive law. In other words, the custom of the town meant more than any social policies created by political authorities. ${ }^{92}$ In fact, the main function of the colonial judicial system was to "punish and restrain crime and to maintain a cooperative harmony in the community,"93 something that the local citizens were only too happy to undertake. Criminal justice functioned as social drama, ${ }^{94}$ and the community often was the law. As such, the jury right was often simply an arm of the community's decision-making power. How these communities used this power varied from colony to colony and from town to town.

\section{New England}

In the seventeenth century, Puritan Massachusetts had formidable social control of its members through the church, and the legal system largely served to reinforce common ideals. ${ }^{95}$ As historians have noted, it is hard to overemphasize the influence of religion in creating a distinctive legal culture, particularly in the "Puritan north.,"96 Informal agencies such as the town meeting and the church congregation served just as often as did the courts in dispute resolution. ${ }^{97}$

Nonetheless, New England colonies very early in their existence generally recognized the right of the accused to be tried by a jury. ${ }^{98}$ The institution of the grand jury was established as early as $1635 .{ }^{99}$ The right to a civil jury trial was guaranteed in New Plymouth in $1623 .{ }^{100}$ The heterodox colony of Rhode Island provided jury trials in the towns even prior to establishing colony government, and its 1647 code guaranteed the jury trial right. ${ }^{101}$ Connecticut, with the exception of the New Haven colony, ${ }^{102}$ expressly granted the right to a criminal jury trial in 1673 , and juries were

founding).

91. William E. Nelson \& Robert C. Palmer, Liberty and Community: Constitution AND RIGHTS IN THE EARLY AMERICAN REPUBLIC 20 (1987).

92. See NELSON, supra note 85 , at 29.

93. Pole, supra note 89 , at 132.

94. See Lawrence M. Friedman, Crime and Punishment in American History 25 (1993).

95. See Warren M. Billings, Law in Colonial America: The Reassessment of Early American Legal History, 81 MiCH. L. REV. 953, 956 (1983).

96. FRIEDMAN, supra note 94 , at 32.

97. See Billings, supra note 95 , at 957.

98. See Edgar J. McManus, Law and Liberty in Early New England: Criminal JUSTICE AND DUE PROCESS, 1620-1692, at 99 (1993).

99. Pole, supra note 89, at 126.

100. See Julius Goebel, King's Law and Local Custom in Seventeenth Century New England, 31 ColuM. L. ReV. 416, 436 (1931).

101. See MCMANUS, supra note 98 , at 99.

102. New Haven was the only colony to try all offenders by judges rather than juries, most likely due to its heavy reliance on Scripture to rule the colony. See id. at 100. 
impaneled well before that by the courts. ${ }^{103}$ Even New Haven chose "flit [sic] and able men, from amongst themselves, being church members as before, to be the ordinary judges, to heare [sic] and determine all inferior causes, whether civill [sic] or criminal." 104 Finally, Massachusetts provided for jury trial in virtually all felonies, and serious crimes were required to go through a jury trial unless the defendant expressly waived the right. ${ }^{105}$

Massachusetts juries in particular had great power in both civil and criminal cases. ${ }^{106}$ The consensus-building and common ethical values present in the Bay colony communities made the role of the jury relatively simple: promulgating moral standards reinforced by the church. All parts of the legal system were continually under the scrutiny of the community as a whole, responding to community needs and interests. ${ }^{107}$ In general, seventeenth-century juries determined the facts and the law "against a template of community norms and served a mediating function between law and society." 108

Public sanction was another critical way in which the New England colonies punished offenders. This was particularly true in the seventeenth century, where punishment tended to be extremely public and often shame-based. ${ }^{109}$ As time went on, however, the public humiliation factor became just one of many expressive options. In eighteenth-century Farmington, Connecticut, for example, there were a series of enactments that protected both life and property by requiring public sanctions along with whatever other punishment was imposed through private actions. ${ }^{110}$

Even after the force of the Puritan ideals slackened through time, the jury's mediating function between law and society remained. As the Massachusetts colony evolved and grew, shaking off the tight grip of the church, the legal order-still almost entirely filtered through the jury trial- "became the pattern after which a coherent society might be fashioned."111

Because all colonial juries determined both the law and the facts, they were the ultimate arbiters of justice. Courts could not grant a new trial if a civil jury ignored the law, and juries could not be forced to adhere to the court's legal instructions. ${ }^{112}$ In the colonies, then, the community's determinations of restorative and retributive justice, as

103. See id.

104. Government of New Haven Colony: October 27/November 6, 1643, art. II, available at http://avalon.law.yale.edu/17th_century/ct02.asp.

105. See MCMANUS, supra note 98 , at 99 . Granted, in the very early days of the colony (i.e., before 1660), the difficulty of impaneling juries meant that there were fewer jury trials. Id. at 103.

106. See NELSON, supra note 85 , at 3 .

107. See id. at 15 .

108. Bruce H. Mann, Law, Legalism, and Community Before the American Revolution, 84

MiCH. L. REV. 1415, 1425 (1986).

109. See Friedman, supra note 94 , at 37.

110. See Richard Gaskins, Changes in the Criminal Law in Eighteenth-Century Connecticut, 25 AM. J. LEGAL HIST. 309, 323 (1981).

111. Billings, supra note 95 , at 956 .

112. See William E. Nelson, The Eighteenth-Century Background of John Marshall's Constitutional Jurisprudence, 76 MICH. L. REV. 893, 913-15 (1978). 
mediated through the local justice system, continued to resonate even after the rigid hold of the Puritans had dissipated.

\section{New York}

Not all colonies had strong religious underpinnings, of course. New York was both haphazard and fairly lenient when it came to punishment in its early days, in large part due to the ethnic antagonism caused by the English conquest of the colony in $1664 .^{113}$ From very early on, however, New York was jealous of its jury trial rights.

In 1683, the New York General Assembly passed a Charter of Liberties and Privileges, specifying three separate times that any criminal offender had the right to be tried by a jury. The Charter held:

THAT Noe freeman shall be taken and imprisoned or be disseized of his ffreehold or Libertye or ffree Customes or be outlawed or Exiled or any other wayes destroyed nor shall be passed upon adjudged or condemned But by the Law-full Judgment of his peers and by the Law of this province ... . ALL Tryalls shall be by the verdict of tivelve men, and as neer as may be peers or Equalls And of the neighbourhood and in the County Shire or Division where the fact Shall arise or grow. . . . THAT In all Cases Capitall or Criminall there shall be a grand Inquest who shall first present the offence and then twelve men of the neighbourhood to try the Offender who after his plea to the Indictment shall be allowed his reasonable Challenges. ${ }^{114}$

Likewise, the Judiciary Act of 1691 reaffirmed the right to a jury trial and enshrined the jury's responsibility to determine questions of fact. ${ }^{115}$

Colonial New York's dedication to the right to a jury trial was exemplified through two prominent cases: the Zenger trial ${ }^{116}$ and the case of Forsey v. Cunningham. ${ }^{117}$ Both these cases publicized the rights of the jury and made them resonate for the colonists.

For our purposes, the most significant aspect of the Zenger trial was the argument that colonial juries should on principle have broader prerogatives than English ones, because of the differences in forms of government. ${ }^{118}$ If we interpret this argument to mean that the community element was more powerful in the colonies than in England, as has been suggested by other scholars, ${ }^{119}$ then the ringing endorsement of the Zenger

113. See Greenberg, supra note 83 , at 300 .

114. N.Y. CONST. of 1683 , art. XIII, XVII, XVIII, available at http://www.montauk.com/history/seeds/charter.htm (emphases and unusual spellings in original).

115. Matthew T. Tulchin, An Analysis of the Development of the Jury's Role in a New York Criminal Trial, 13 J.L. \& PoL'Y 425, 443 (2005).

116. Tried for criminal seditious libel, Zenger carried the jury against the instructions of the court and garnered an acquittal, becoming famous as an example of the jury's power to overrule the court. See LeONARD W. LEVY, LEGACY OF SUPPRESSION: FREEDOM OF SPEECH AND PRESS IN EARLY AMERICAN HISTORY 133 (1960).

117. In Forsey, an assault and battery case, the jury refused to follow the law and awarded the complainant $£ 1500$. See Pole, supra note 89 , at 130.

118. See id. at 127.

119. See id. 
trial's outcome by the colonists reinforced the power of the community's voice in the law.

In Forsey, the colonial governor's review of the case caused an uproar regarding the executive usurpation of traditional jury rights. Here, "the jury was not merely determining a legal dispute but was perceived, once again, as a threatened agent of the popular interest." 120 The potential diminution of jury rights was seen as a quashing of the community voice to participate in local disputes, and was unacceptable to colonial New Yorkers.

This fidelity to the jury's power remained true well past the War of Independence; even after 1800 , New York judges did not always agree that they could set aside verdicts against law or evidence. ${ }^{121}$ In seventeenth- and eighteenth-century New York (and in most other jurisdictions of that time), the power of the jury reigned supreme. ${ }^{122}$

And this supreme power of the jury was almost exclusively viewed as the right of the people. Contemporary newspaper accounts bear this out. In August of 1735, the New York Weekly Journal printed part of a tract entitled "A Dialogue between a BARRISTER at LAW, and a JURYMAN"'23 that discussed "the Antiquity, Use, Power and Duty of JURORS, by the Law of England." 124 This pamphlet, originally printed in England in 1680, and periodically reprinted thereafter, ${ }^{125}$ was a popular explanation of the jury trial right, emphasizing its collective nature. ${ }^{126}$

The part of the tract reprinted in the New York Weekly Journal discussed "the Nature of [a Jury's] Office and Power by Law." ${ }^{127}$ As such, it is an excellent example of how the right of jury trial was commonly understood during the eighteenth century. ${ }^{128}$

Throughout the "discussion" between the Barrister and the Juryman, a few major themes emerge. First and foremost, the people's role as the only "proper Judges of the Matter in Issue before them" 129 emerged as the primary lesson. Stated differently, the author was keen to impress on his audience that the court had little to do with criminal adjudication, since in all criminal matters, "the Prisoner is said to put himselffor Trial upon his Country . . . to be meant of the Jury, saying to them, which Country you are." 330 This phrase, "to put himself for Trial upon his Country," meant that the prisoner was literally putting himself in the hands of the local community to determine his fate.

120. Id. at 130 .

121. Nelson, supra note 112, at 915.

122. See id. at 916.

123. Sir John Hawles, A Dialogue Between a Barrister at Law and a Juryman, Concerning the Antiquity, Use, Power, and Duty of Jurors, by the Law of England, N.Y. WKLY. J., Aug. 2, 1735 , at 1.

124. Id.

125. See Sir John Hawles, The Englishman's Right: A Dialogue Between a Barrister AT LAW AND A JUR YMAN 8 (Edes \& Gill 1772) (1771).

126. Id. at $\mathrm{v}$.

127. Id. at 18 .

128. The 1735 date of the newspaper publication makes it highly likely that it was in response to the Zenger trial, which in 1735 stirred up the issue regarding the jury's ability to judge the law as well as the facts.

129. Hawles, supra note 123.

130. Id. (emphases in original). 
Nowhere in the tract, however, do we see any discussion of how the jury trial had much to do with the rights of the accused. This is highlighted by the enumeration of what the defendant's rights were at that time assumed to be. Most imperative was the right of the defendant to "be allowed his lawful challenges," defendant's right to present evidence and witnesses. ${ }^{132}$ On the other hand, the people's right was to comprise a jury and pass judgment, in order to determine "Truth" (which at this time was closely linked to their ability to judge "Matters of Law"). ${ }^{133}$

The only linkage of the defendant's rights and the jury trial right comes at the very end of the tract, where, in oratory form, the author proclaims that "the End of Juries is to preserve Men from Oppression ...."134 But even this statement can be interpreted as a nod to the community's role and power. The "Oppression" the author speaks of is not necessarily the defendant's, but the people's - the oppression that results from nonlocal decision makers (whether judges, magistrates, Parliament or the Crown) eliminating the jury's ability to decide on their own.

Reviewing the tract in its entirety, as it was originally published in both England and the colonies, only underlines this point. In the Preface, the essential nature of the jury trial is summarized in a sentence:

As the people of England cannot be bound by any law, without the consent of their representatives first had in parliament; so neither can any Englishman suffer in his person, or estate, for the breach of any laws, or for any real, or pretended crime, without the consent of the people first had by a jury of his peers, or equals. ${ }^{135}$

In other words, the right of the jury trial, according to the pamphlet, is all about representation, or the participation of the citizenry in rule of law. Fairness to the defendant plays a part, of course, but the right emphasized over and over again is that belonging to the local community and to the people at large.

This point is made again on the very next page, where the author links the very "security of the nation" to battling any limitations on jury rights:

[E]ncroachments have lately been made upon the rights of Juries. To enquire into the truth of this charge is of the utmost consequence, not only to Jurors, but to the whole body of the people; as there is no man who may not, directly, or indirectly, be affected by these invasions. ${ }^{136}$

Again, taking away any aspect of the jury trial (here, the ability to judge the law) is seen as harming national security by stealthily removing the long-held rights of the people. The rights of the criminal offender entered the picture only as a far distant second.

In both New York and the other colonies, then, colonials relied on juries to maintain and reify their social values through the criminal law. Such shared social values were

131. Id. (emphasis in original).

132. See id.

133. Id. at 2 (emphasis in original).

134. Id. at 3 (emphasis in original).

135. HAWLES, supra note 125 , at v.

136. Id. at vi (emphasis in original). 
one reason that most socioeconomic decisions-including the application of substantive criminal law-were made at the local level. These shared values allowed local juries to decide both law and fact with little problem. William Nelson argues that since most jurors came to court with remarkably similar views about the substance of the law, it is possible to infer that most jurors had a "body of shared ideas about law."137

In light of these shared legal ideals, it made sense to leave most of the determinations of criminal justice to the jury, since jury duty was most likely distributed among a "random and representative cross section" of the white, male, landowning, and taxpaying population. ${ }^{138}$ In colonial America, decisions on criminal justice-and community governance-trickled up. Juries took an active and critical role in self-government, both by translating the law down to the community and by translating values up to the governing bodies. ${ }^{139}$

This pattern of local governance in the criminal law arena would continue through the War of Independence and beyond, despite the vast changes in almost all other areas. The people's right to the jury trial would not only remain unchanged, but end up gaining even more power in the Constitutional era.

\section{FROM LOCAL POWER TO THE COLLECTIVE JURY TRIAL RIGHT}

The American Revolution created much change in the patterns of justice in the colonies. ${ }^{140}$ As Roscoe Pound noted, American criminal justice became "distinctively American" in the eighteenth century. ${ }^{141}$ "Both during and after the conflict for independence, citizens of all the towns turned more fractious, and the informal agencies declined in their effectiveness as more suitors sought relief through the courts." $" 142$

Although the war itself did not spark much legal change, the revolutionary government's attempts to explain both the war and its political results "set loose new intellectual and social currents which ultimately transformed the legal and social structure of the new state." 143 Despite this transformation, the jury trial would retain its centrality in this sea change from old to new.

At the beginning of the War of Independence, the majority of colonists wished to maintain the general political structure. ${ }^{144}$ Most wanted to keep an order "which generally required officials to govern according to common values or principles which nearly all citizens accepted as right or otherwise legitimate." 145 Although the colonial political structure would be thoroughly upended, ${ }^{146}$ the colonists had a strong desire to

137. Nelson, supra note 112 , at $918-19$.

138. Id. at 919 .

139. See Shannon C. Stimson, The American Revolution in the Law: Anglo-American JURISPRUDENCE BEFORE JOHN MARSHALL 59-61 (1990).

140. Billings, supra note 95 .

141. N. Roscoe Pound, Criminal Justice IN America 117 (1930).

142. Billings, supra note 95 .

143. NELSON, supra note 85 , at 5 .

144. Nelson, supra note 112, at 924.

145. Id. (emphasis added).

146. See id. at 924-25. 
maintain the role of common principles. It was this desire-combined with the theory that all law springs from popular will ${ }^{147}$-that placed the role of the community and the jury in the center of American ideals of government and justice.

These ideals of government and justice were envisioned as specifically American and independent. ${ }^{148}$ During the Revolutionary era, as in the Colonial era that preceded it, law was "mediated to society" through the courts and the representative roles of the grand and petit juries. ${ }^{149}$ Juries and the judicial process provided a critical contribution in both the social psychology and substance of the representative nature of new government. ${ }^{150}$ In other words, much of the heft of America's new representative government came from the jury's key role in dispensing not only the law to the community, but also in its role maintaining the community's centrality to politics and the polity. The jury trial right was key to both.

\section{A. Legal and Political Theory}

The role of the community in interpreting and mediating law was given great support by the legal writers and theorists read by the colonists before, during, and after the Revolution. One much-read author was Sir Edward Coke. Coke was a highly influential theorist at the time of the formation of the American Constitution. ${ }^{151}$ His Institutes of the Laws of England, originally published in the Elizabethan age, shaped the understanding of English law for generations, and was very familiar to the colonies' educated class. ${ }^{152}$

Coke's discursions on the workings of the jury trial made clear that the right belonged to the county, or community, where the accused had committed the crime. In his discussion of where an Englishman should be tried for treason, Coke's gloss on Edward Littleton, the fifteenth century English jurist, explains that "it shall be tried by twelve men of the countie [sic], where the kings [sic] bench shall sit ..." ${ }^{153}$ Likewise, in a more detailed exposition on petit treason, Coke notes that the decision in such cases rests on "trialls [sic] by the verdict of twelve men de vicineto, of the place where the offence is alleadged [sic] ...."154

Nowhere in Coke is there the notion that the twelve man jury trial was a right of the accused. Instead, the focus was consistently on the area from which the jurors were chosen. For Coke, the importance of the local, as translated through the literal site of the jury trial and its composition, was part and parcel of the jury trial right.

Matthew Hale's History of the Common Law, penned in 1713, also helped shape eighteenth-century American lawmaking, and was deeply concerned about the scope

147. Id. at 925.

148. See Pole, supra note 89 , at 123.

149. Id. at 125 .

150. See id.

151. See generally Allen D. Boyer, SiR EdWARD COKE AND the ElizABETHAN AGE (2003).

152. See id.

153. SIR EDWARD COKE, Of Continuall Claime, in 2 THE FIRST PART OF THE INSTITUTES OF THE LAWS OF ENGLAND, OR, A COMMENTARY UPON LITTLETON 261 (19th ed. Garland Publ'g 1979) (1628).

154. SiR Edward Coke, Petit Treason, in The ThIRD AND Fourth Parts of THE INSTTTUTES OF THE LAWS OF ENGLAND 19, 26 (19th ed. Garland Publ'g 1979) (1644) (emphasis added). 
and meaning of the jury trial right. Hale's first remark about England's criminal courts focused, unsurprisingly, on the role of the jury trial: "no man shall be put out of his lands or tenements, or be imprisoned by any suggestion, unless it be by indictment or presentment of lawful men, or by process at common law." ${ }^{155}$ Similarly, in discussing the parallels between Norman and English law, Hale noted that in England, "in cases of trials by twelve men, ALL OUGHT TO AGREE, and any one dissenting, no Verdict can be given." 156

Like Coke's Institutes, Hale's discussion of the jury trial concentrated largely on the selection and nature of the jurors comprising the jury, which he lauded as "an institution most admirably calculated for the preservation of liberty, life, and property." 157 Note the phrasing: An institution, not an individual right. And a key aspect of this institution was that jurors were to be chosen from those who lived, preferably, in the neighborhood, or at least the county or bailiwick. ${ }^{158}$ As Hale explains in a footnote:

[T] he jury was to come de vicineto, from the neighbourhood of the place where the action was laid; and therefore, they were summoned from the very hundred in which the cause of action arose; ... [1] iving in the neighbourhood, they were most unquestionably of the very county, or pais, to which both parties had thought proper to appeal .... 159

The significance of this passage lies in Hale's focus on the local derivation of the jurors. Of the four aspects of the jury Hale mentioned, it is only this neighborhood requirement that Hale deemed imperative enough to devote a page-long explanation. ${ }^{160}$ The existence of four separate terms to delineate the locality of the jury trial right-de vicineto, neighbourhood, county, and hundred-denoted the inseparable nature of the community and the jury trial right. The judgment of the local community was part and parcel of the jury trial right, as understood by Hale and his contemporaries.

One of these contemporaries, Cesare Beccaria, also had great influence on Founding era thinkers and writers. Beccaria, an Italian political theorist, was well known in his native country, in England, and in the colonies. This is evidenced by the American reprinting of his best known work, Dei Delitti e Delle Pene, or An Essay on Crimes and Punishments, during a crucial time in the emerging American nation. Most notably, editions of Beccaria's Essay were translated from the Italian to English and printed in Charlestown, South Carolina in $1777^{161}$ and in Philadelphia in $1778 .^{162}$

Beccaria's Essay covered many topics, but most significant were his discussions of public trial and punishment. The Essay's paean to the trial by peers emphasizes the role

155. Matthew Hale, The History of the Common Law of England, and an ANALYsis of THE CIVIL PART OF THE LAW 50 (Charles Runnington ed., 6th ed. 1820) (1713).

156. Id. at 150 (emphasis in original).

157. Id. at 336 .

158. Id. at 338 .

159. Id. (emphasis in original).

160. Id.

161. Cesare B. Beccaria, An Essay on Crimes and Punishments (Charlestown, S.C., David Bruce 1777).

162. Cesare B. Beccaria, An Essay on Crimes and Punishments (Phila., R. Bell 1778). 
of the community in this aspect of criminal justice, with a particular twist-comprising half of the jury from the offender's peers, and half from the victim's peers:

It is an admirable law which ordains, that every man shall be tried by his peers.... But when the crime is an offence against a fellow subject, one half of the judges should be peers to the accused, and the other, peers to the person offended. ${ }^{163}$

Notably, Beccaria's conceptualization of a jury of one's peers did not assume that the "peers" in question belonged solely to the accused. Instead, he envisioned the jury, or "proto-jury," as partially comprised of the peers of the defendant, and partially comprised of peers of the victim.

By understanding the jury right as such, it seems apparent that Beccaria viewed the jury as the community's right rather than as primarily the defendant's right. In proposing that even the jury pool belonged equally to the victim and to the accusedas opposed to the general view that the jury pool should be entirely comprised of the defendant's peers-Beccaria's position supported a strong community-based jury right.

Moreover, Beccaria fervently espoused a public trial, which he saw as critical in establishing and strengthening the people's rights:

All trials should be public; that opinion which is the best or, perhaps, the only cement of society, may curb the authority of the powerful, and the passions of the judge; and that the people may say, "We are protected by the laws; we are not slaves." 164

Beccaria's belief that any trial and resulting judgment should be performed openly became part of the common belief that the jury was a popular bulwark against government and sovereign oppression. But by emphasizing the importance of the public's opinion, as well as the openness of any trial, Beccaria also underlined the importance of the people's involvement in the criminal justice process-“"the only cement of society." 165

Likewise, in the course of discussing secret accusations, Beccaria asked, rather dramatically, "can there be any crime, committed against the public, which ought not to be publicly punished?"166 Thus, even writing from a tradition which did not use the jury as a way to involve the community in an offender's trial and punishment, Beccaria still viewed crime as a wrong "committed against the public," something that ought to be "publicly punished.",167

This philosophy of punishment fit well with the colonial understanding of the community's right to judge an offender and penalize him, openly and in full view of the populace. In other words, Beccaria's understanding of punishment supported an expressive, retributive punishment philosophy, one which fit well into the existing American framework.

163. BECCARIA, supra note 161 , at 29.

164. Id. at 30.

165. Id.

166. Id. at 32 .

167. Id. 
Perhaps the most influential legal writer for the fledgling Americans was William Blackstone. His Commentaries on the Law of England, ${ }^{168}$ published in the mid-1760s, quickly became a cornerstone for developing American jurisprudence. ${ }^{169}$ Blackstone's masterpiece was repeatedly printed in the colonies, and was widely read before, during, and after the War of Independence. ${ }^{170}$ It is useful, then, to look at Blackstone's discussion of the jury trial to better comprehend the late eighteenth-century meaning of the institution.

Blackstone first explored civil juries, and although our interest primarily concerns criminal juries, his account of the civil jury's procedure is helpful. In the first five pages of the chapter, Blackstone focused on the rights of the people comprising the jury. He spent considerable ink detailing the importance of having the case heard by local jurors at a local site- for the convenience and rights of both the jurors and the parties. $^{171}$

The discussion of the parties' rights was limited to three aspects: their right to challenge jurors; the "inconvenience"172 caused not having the names of the jurors available before trial, since this would make it more difficult for the parties to research them; and the savings in cost for the parties by having the jurors impaneled locally (since at that time, the parties bore all court costs). ${ }^{173}$

Blackstone specifically mentioned the local composition of the jury-and the local site of the trial-as a key part of the "investigation of truth."174 This ferreting out of the truth was, for Blackstone, the central aspect of the civil trial, and could only be done by the surrounding community.

Blackstone also returned to the roots of the jury trial to show the close relationship between the composition of the jury from the local community and the ability to properly judge the defendant:

$[B] y$ the policy of the ancient law, the jury was to come de vicineto, from the neighborhood of the vill or place where the cause of action was laid in the declaration .... For, living in the neighborhood, they were properly the very country, or pais, to which both parties had appealed; and were supposed to know before-hand the characters of the parties and witnesses, and therefore the better knew what credit to give to the facts alleged in evidence. ${ }^{175}$

In this way, Blackstone rooted the entire theory underlying trial by jury in the village or country in which the cause was tried. Although Blackstone later noted that the practice of impaneling jurors from the actual neighborhood had been abolished in

168. 3 SiR William Blackstone, Commentaries on the LaW OF ENGLAND (Robert Bell 1772) (1765), available at http://avalon.law.yale.edu/subject_menus/blackstone.asp\#book3.

169. See Pole, supra note 89, at 143.

170. See Greg Bailey, Blackstone in America, EARLY AM. REV., Spring 1997, available at http://www.earlyamerica.com/review/spring97/blackstone.html.

171. See 3 BLACKSTONE, supra note 168 , at 351-55.

172. See id. at 353.

173. See Laurie Edelstein, An Accusation Easily to Be Made: Rape and Malicious Prosecution in Eighteenth-Century England, 42 AM. J. LEGAL HIST. 351, 373 (1998).

174. See BLACKSTONE, supra note 168 , at 355 .

175. Id. at 359-60 (emphasis in original). 
favor of the larger county, due to concerns over too much prejudice, ${ }^{176}$ his focus remained on the importance of having the surrounding community's direct participation in the trial.

Blackstone's repeated insistence that the English system of jury trial provided the best procedure for discovering truth is itself telling. In listing and praising the laws of England, Blackstone consistently contended that the jury trial was the best and fairest procedure. ${ }^{177}$ This was due, however, to the jury trial's ability to come to the correct judgment (through the community's imprimatur), not because of its preservation of the rights of any individual defendants. ${ }^{178}$ In other words, Blackstone valued the right of trial by jury for its "test[ing] and investigation of truth."

Blackstone returned to the collective nature of trial by jury in chapter twenty-seven, where his praise is revealing. In lauding the practice in criminal cases, he literally defines it as that great right of the people, stating that "the trial by jury, or the country, per patriam, is also that trial by the peers, of every Englishman, which, as the grand bulwark of his liberties, is secured to him by the great charter ...." ${ }^{80}$ That is to say, the criminal jury trial right is explained as per patriam, or by the country, or by the peers. This "grand bulwark" of liberties is provided to "every Englishman" by giving the right of judgment to the community.

Blackstone reiterated this collective understanding of the criminal jury trial right by explaining it in further detail in the following paragraph, once again defining it as the right of the people. In exploring why the criminal jury trial right is even more essential than the civil jury trial right, Blackstone pointed out that the community must mediate and protect itself from the prerogatives of the Crown:

But the founders of the English laws have with excellent forecast contrived, that no man should be called to answer to the king for any capital crime, unless upon the preparatory accusation of twelve or more of his fellow subjects, the grand jury: and that the truth of every accusation, whether preferred in the shape of indictment, information, or appeal, should afterwards be confirmed by the unanimous suffrage of twelve of his equals and neighbours, indifferently chosen, and superior to all suspicion. ${ }^{181}$

Note how Blackstone cast the first right-the grand jury — as a right of the individual. "No man" could be held accountable for any capital crime unless first indicted by twelve fellow subjects. The second right, however, is separate, through both punctuation and phrasing. Blackstone's description differentiates the petit jury from the grand jury both for its role-rooting out the truth-and its focus. For Blackstone, the critical aspect of the petit jury was its local composition, "twelve of his equals and neighbours," and the unanimous agreement of the accused's community on his guilt.

176. Id. at 360 .

177. See id. (noting throughout that the jury trial was the best and fairest procedure).

178. See id. at 365 .

179. Id.

180. 4SIR WILliam BLACKSTONE, COMmentaries ON THE LAW OF ENGLAND 342 (Robert Bell 1772) (1765), available at http://avalon.law.yale.edu/18th_century/blackstone_bk4ch27.asp (emphasis added).

181. Id. at 343 . 
If Blackstone had meant to ascribe the petit jury right solely to the accused, he would not have delineated it, in description and language, from the grand jury right, which was always the defendant's prerogative. Instead, Blackstone elucidated the criminal jury trial right as one that belonged to the local peers of the accused, who had to be unbiased so that the community could properly determine guilt and find punishment.

Blackstone ended his discussion of the criminal trial by referencing Beccaria to explain how guilty pleas and even voluntary forgiveness were "contrary to the good of the public," 182 since they put stop to the essential function of the criminal jury trial. As Blackstone, quoting Beccaria, notes:

[A]lthough a private citizen may dispense with satisfaction for his private injury, he cannot remove the necessity of public example. The right of punishing belongs not to any one individual in particular, but to the society in general, or the sovereign who represents that society: and a man may renounce his own portion of this right, but he cannot give up that of others. ${ }^{183}$

In other words, Blackstone's message was that the primary purpose of the criminal jury trial was not to give rights either to the accused or the victim. Rather, the jury trial's overarching role - that of determining truth and dispensing punishment-belonged to the public, or "society in general." The "necessity of public example" was a key part of the criminal jury trial right, or the right of the local community to publicly adjudicate any alleged crimes committed against it.

One reason Blackstone was so influential was because many of the Revolution's key players, and more than half of the Constitutional Convention's delegates, were lawyers or legally trained. ${ }^{184}$ Accordingly, the understanding of the jury trial right by contemporary lawyers was influential as well. Most of these lawyers understood the criminal justice system through the lens of English common law. As such, contemporary writing discussing the role of juries provides excellent documentation of what the jury trial right was understood to be.

An essay written by Joseph Towers and Francis Maseres, entitled An Enquiry into the Question, Whether Juries Are, or Are Not, Judges of Law, As Well as of Fact; with a Particular Reference to the Case of Libels, ${ }^{185}$ is one such source. The essay focuses on the right of the criminal jury to determine both fact and law in matters of libel, and in doing so, lays out the community aspect of the jury trial right.

The authors explained that since the Magna Carta, the phrase "no man may be charged but by the lawful judgment of his peers" meant that "no man can be legally punished, in any way whatever, without a fair trial by a jury of twelve men; and without

182. Id. at 358 .

183. Id. at 343 (emphasis added).

184. DANIEl A. FARBER \& SUZANNA SHERRY, A History of THE AMERICAN CONSTITUTION 8 (2d ed. 2005).

185. Joseph TOWERS \& Francis MASERES, AN ENQUIRY INTO THE QUESTION, WhETHER JURIES ARE, OR ARE Not, JUDGES OF LAW, As WELl AS OF FACT; WTTH A PARTICULAR REFERENCE TO THE CASE OF LIBELS (1764), available at http://www.constitution.org/jury/cmt/towers/towers.htm (unusual capitalization in original). 
their finding him guilty of some crime which the law declares punishable." ${ }^{, 186}$ In other words, the phrasing of the clause, despite its sound to our modern ears, did not mean an individual right, but a collective right--plural rather than singular.

Finally, we see the belief in a collective jury trial right in the writings of influential American lawyers such as John Adams. In his diary, Adams devoted a considerable section to the people's rights, discussing the jury's function and role in the "administration of justice," where the people had "an important share." "187

As Adams explained, juries, and the jury trial right, were derived from "the mass of the people, and no man can be condemned of life, or limb, or property, or reputation, without the concurrence of the voice of the people."188 To Adams, and to the other intellectuals and lawyers of his time, the jury trial right was inseparable from the community's prerogative, derived as it was from the "common people."189

More specifically, Adams believed that the right to hold trial and decide on a verdict belonged not just to the people en masse, but to each juror in particular: "It is not only his right, but his duty . . . to find the verdict according to his own best understanding, judgment and conscience, though in direct opposition to the direction of the court."190 Significantly, Adams was the originator of the Massachusetts Constitution, which, as I discuss below, had early on embedded the jury trial right as a community entitlement. The majority of the states highly valued the jury trial right, and, as I will show, viewed it primarily as a collective prerogative, belonging to the populace in general, not to any individual accused.

\section{B. State Jury Trial Rights}

Even before the first Continental Congress, many state legislatures and congresses made declarations about the importance of the jury trial right as a community right. For example, on August 25, 1774, the Provincial Congress of North Carolina proclaimed "that trial by juries of the vicinity is the only lawful inquest that can pass upon the life of a British subject ...."191

The Journal of the Proceedings of the Congress, held at Philadelphia, September 5, 1774 , reflects this understanding of the collective jury right as well. In the Journal's discussion of rights, the second right elucidated is the right to a jury trial. ${ }^{192}$ This jury trial right is explained as the right of the offender's community:

The next great right is that of trial by jury. This provides, that neither life, liberty nor property can be taken from the possessor, until twelve of his unexceptional countrymen and peers, of his vicinage, who from that neighbourhood may

186. Id. at 4 .

187. 2 JOHN Q. ADAMS, THE WORKS OF JOHN ADAMS 253 (Little \& Brown 1850).

188. Id.

189. See id.

190. Id. at 255 .

191. Minutes of the Provincial Congress of North Carolina (Aug. 25, 1774), in 9 THE COLONIAL RECORDS OF NORTH CAROLINA 1041-43 (William L. Saunders ed., 1886), available at http://docsouth.unc.edu/csr/index.html/document/csr09-0303.

192. U.S. Cont'l Cong., Journal of the Proceedings of the Congress, Held at PhILADELPHIA, SEPTEMBER 5, 1774, at 121(1774). 
reasonably be supposed to be acquainted with his character, and the characters of the witnesses, upon a fair trial, and full enquiry face to face, in open Court, before as many of the people as chuse [sic] to attend, shall pass their sentence upon oath against him .... ${ }^{193}$

Following this discourse on the jury trial right, the next right discussed in the Journal is "the liberty of the person"- that is, a personal right, one focused "merely" (that is, directly) on the person. ${ }^{194}$ The separation of these two rights-the jury right, or that belonging to the community, and the right of liberty, that belonging to the individual person-was not arbitrary.

Another key aspect of the jury trial right, as understood at the time and incorporated into the Continental Congress's proceedings, was the local community's right to participate in the trial. This was done by holding the proceedings in open court "before as many of the people as chuse [sic] to attend. "195 By doing away with secret trials, the jury trial right existed to preserve the open, public aspect of justice. A jury trial was an expressive right possessed and practiced by the entire local community, not just those who were chosen for the jury.

Moreover, the defendant's right of "full enquiry face to face, in open Court,"196 if interpreted in the meaning of the times, did not concern the jury trial right, but instead referred to the right of confrontation. Witnesses had to confront the accused in open court so that the local populace could judge for themselves the truth of the matter, whether they were in the jury itself or just spectators. Thus, the public, expressive aspect of the jury trial was inextricably bound with the community's rights at the time of the Continental Congress.

This view of the jury trial right can be found in the October 14, 1774 Declaration and Resolves of the First Continental Congress. ${ }^{197}$ In its discussion of the "infringements and violations" "198 of colonists' rights by certain parliamentary acts, and its complaints about how England's new dockyard act "deprives the American subject of a constitutional trial by jury of the vicinage,"199 the Declaration specifically linked the jury trial right with the community. Stated differently, the very essence of the ancient jury trial right, for the rebellious colonists, was synonymous with the local community. If the local community did not try the accused, then the jury right was no right at all.

Although aware of the dangers of local prejudice, Americans of the Revolutionary era fervently believed that "only local juries could fulfill the adjudicative and representational purposes that underlie the jury system."200 Revolutionary colonists

193. Id. at 121-22.

194. Id. at 122.

195. Id.

196. Id.

197. Declaration and Resolves of the First Continental Congress (Oct. 14, 1774), reprinted in DOCUMENTS ILluSTRaTIVE OF THE FORMATION OF THE UNION OF THE AMERICAN STATES 1 (Charles Callan Tansill ed., 1927), available at http://avalon.law.yale.edu/18th_century/resolves.asp.

198. Id. at 4.

199. Id. at 5 .

200. Engel, supra note 8, at 1673. 
understood that the jury trial right was inextricably linked to the moral judgment of the community, and ultimately constructed the constitutional right to a jury trial based on that understanding.

Following the War of Independence, many states, as well as the Northwest Ordinance, secured the right to a collective jury trial. ${ }^{201}$ Georgia's constitution specified that all criminal cases must go to trial in the same community in which the crime was committed: "All matters of breach of the peace, felony, murder, and treason against the State to be tried in the county where the same was committed." ${ }^{202}$ Georgia made no mention of the rights of the accused. Likewise, Maryland's constitution proclaimed in its third article that "the inhabitants of Maryland are entitled to the common law of England, and the trial by jury, ${ }^{, 203}$ but never ascribed the jury trial right to the individual.

John Adams wrote the constitution for the Commonwealth of Massachusetts, and infused into it his conception of the local, community-centered jury right. In Article XII, the jury trial right reads "no subject shall be arrested, imprisoned, despoiled, deprived of his property, immunities, or privileges, put out of the protection of the law, exiled, or deprived of his life, liberty, or estate, but by the judgment of his peers, or the law of the land. ${ }^{204}$ This was in contrast to the individual rights of the accused, like the right to present proof, the right of confrontation, and the provision of a defense. ${ }^{205}$ The jury trial right simply was not viewed as an individual right when Adams wrote the state constitution.

New Jersey also preserved the right to jury trial, but took the further step of delineating certain individual rights as well. In Article XVI, the New Jersey Constitution preserves the rights of all defendants to "the same privileges of witnesses and counsel, as their prosecutors are or shall be entitled to." 206 These individual rights, however, are entirely separate from Article XXII's discussion of the jury trial, declaring that the common law of England was still viable and that the "inestimable right of trial by jury"207 would always continue to be the law of New Jersey. New Jersey's separation of individual rights and the jury trial right is important, because it signals how the right to a jury trial was not envisioned as individual.

201. See Gaspare J. Saladino, Synthesizing the Origins of the Bill of Rights, H-NET REVIEWs (1999), http://www.h-net.org/reviews/showrev.php?id=3505 (reviewing LEONARD W. LEVY, THE ORIGINS OF THE BILL OF RIGHTS (1999)).

202. Ga. Const. of 1777 , art. XXXIX, reprinted in 2 THE FEDERAL AND STATE CONSTITUTIONS COLONIAL CHARTERS, AND OTHER ORgaNiC LAWS OF THE STATES, TERRITORIES, and Colonies Now OR Heretofore Forming tHe UnIted States of AMERICA 777, 783 (Francis Newton Thorpe ed., 1909), available at http://avalon.law.yale.edu/18th_century/ga02.asp [hereinafter FEDERAL AND STATE CONSTITUTIONS].

203. MD. CONST. of 1776 , art. III, reprinted in 3 FEDERAL AND STATE CONSTTIUTIONS, supra note 202 , at $1687,1686-87$.

204. MASS. CONST. art. XII.

205. Id.

206. N.J. CONST. of 1776 , art. XVI, reprinted in 5 FEDERAL AND STATE CONSTITUTIONS, supra note 202, at 2994, 2587.

207. Id. art. XXII, at 2598. 
Similarly, New York's constitution laid out the collective jury trial right in clear terms, without mention of the individual's right:

And this convention doth further ordain, determine, and declare, in the name and by the authority of the good people of this State, that trial by jury, in all cases in which it hath heretofore been used in the colony of New York, shall be established and remain inviolate forever. ${ }^{208}$

In fact, one of the few mentions of individual rights was specifically premised on the community's right to override them through the jury trial: "no member of this State shall be disfranchised, or deprived of any of the rights or privileges secured to the subjects of this State by this constitution, unless by the law of the land, or the judgment of his peers." ${ }^{209}$ The only other specification of individual rights-the right to counsel-was articulated in a separate article. ${ }^{210}$

North Carolina followed similar course by assigning to the individual the right of confrontation, notice, and preservation against self-incrimination, and banned cruel and unusual punishment and excessive bail. ${ }^{211}$ Like the other states, however, North Carolina placed the right to a jury trial in an entirely distinct article, stating that "no freeman shall be convicted of any crime, but by the unanimous verdict of a jury of good and lawful men, in open court."212 Unlike the individual rights language of its constitution's other clauses, North Carolina's jury trial right was phrased passively, with the focus on the composition of the jury itself, not on the accused. ${ }^{213}$

In contrast, Pennsylvania, ${ }^{214}$ Vermont, ${ }^{215}$ and Virginia ${ }^{216}$ seemed to simultaneously grant the jury trial right to both the individual and the community. The Pennsylvania

208. N.Y. CONST. of 1777 , art. XLI, reprinted in 5 FEDERAL AND STATE CONSTITUTIONS, supra note 202, at $2623,2637$.

209. Id. art. XIII, at 2632.

210. See id. art. XXXIV, at 2635.

211. N.C. CONST. of 1776, arts. VII, X, reprinted in 5 FEDERAL AND STATE CONSTITUTIONS, supra note 202 , at $1287,1287-88$.

212. Id. art. IX, at 2787.

213. See, e.g., id. art. VII, at 2787 (stating "in all criminal prosecutions, every man has a right to be informed of the accusation against him, and to confront the accusers and witnesses with other testimony, and shall not be compelled to give evidence against himself").

214. See PA. Const. of 1776 , art. IX, reprinted in 5 FEDERAL AND STATE ConstituTions, supra note 202, at 3081, 3083 ("That in all prosecutions for criminal offences, a man hath a right to be heard by himself and his council, to demand the cause and nature of his accusation, to be confronted with the witnesses, to call for evidence in his favour, and a speedy public trial, by an impartial jury of the country, without the unanimous consent of which jury he cannot be found guilty; nor can he be compelled to give evidence against himself: Nor can any man be justly deprived of his liberty except by the laws of the land, or the judgment of his peers.").

215. See VT. Const. of 1777 , ch. 1 , art. X, reprinted in 6 FEDERAL AND STATE CONSTITUTIONS, supra note 202, at 3737, 3741 (declaring a right to "a speedy public trial, by an impartial jury of the country; without the unanimous consent of which jury, he cannot be found guilty," and declaring that no man can "be justly deprived of his liberty, except by the laws of the land or the judgment of his peers").

216. See VA. CONST. of $1776, \S 8$, reprinted in 7 FEDERAL AND STATE CONSTITUTIONS, supra note 202, at 3812, 3813 (declaring that a "speedy trial by an impartial jury of twelve men of his vicinage" was critical to the people's rights as citizens). 
Constitution used its ninth article to explain the jury right in terms that clarified the role of the local community in criminal prosecutions, but also presumed some individual aspects of the various rights. ${ }^{217}$

Pennsylvania's Article IX begins generally, explaining that the rights below pertain to "all prosecutions for criminal offences," 118 and then launches directly into the rights of the accused, including the right to counsel, the right to be heard, the right to be confronted with the crime and with the witnesses, and the right to look for evidence. ${ }^{219}$ However, the second half of Article IX's clause delineates the list of individual rights from the collective ones. Using a comma and the word "and," the latter half of the clause separated out the next two rights, those belonging to the community: "and a speedy public trial, by an impartial jury of the country, without which the unanimous consent of which jury he cannot be found guilty."220

Pennsylvania's separation of the jury trial right from the preceding list of individual rights is significant for two reasons. First, as a matter of phrasing, the way the article is written forces the eye to recognize the jury trial as a discrete right--not merely one of the accused's rights listed serially, but a separate and distinguishable right, important in its own accord. This importance of the jury trial right-and the community's stake in it-is underlined by its repeat just a phrase later, stating that no man can lose his rights except by "the judgment of his peers." 221

Second, Article IX specified the community's right to a jury trial no fewer that four times: as a "speedy public trial;" by an "impartial jury of the country;" guilt by "unanimous consent;" and the importance of the "judgment of his peers.",222 This four to one ratio strongly suggests that the jury trial right was primarily envisioned as a privilege belonging to the public and residing in the local district. When compared to the rest of the enumerated rights, which belong solely to the accused, the difference is significant.

The First Continental Congress had a similar understanding of the collective jury trial right. In its October 1774 address to the Province of Quebec, the Congress laid out the jury trial right as the community's, explaining that:

[T] he next great right is that of trial by jury. This provides, that neither, life, liberty nor property, can be taken from the possessor, until twelve of his unexceptionable countrymen and peers of his vicinage ... upon a fair trial, and full enquiry, face to

217. See PA. CONST. of 1776 , art. IX, supra note 214 , at 3083 . Article IX states:

That in all prosecutions for criminal offences, a man hath a right to be heard by himself and his council, to demand the cause and nature of his accusation, to be confronted with the witnesses, to call for evidence in his favour, and a speedy public trial, by an impartial jury of the country, without the unanimous consent of which jury he cannot be found guilty; nor can he be compelled to give evidence against himself: Nor can any man be justly deprived of his liberty except by the laws of the land, or the judgment of his peers.

Id.

218. Id.

219. Id.

220. Id. (emphasis added).

221. Id.

222. Id. (emphasis added). 
face, in open Court, before as many of the people as chuse to attend, shall pass their sentence upon oath against him. ${ }^{223}$

Thus, even in a speech enumerating the confederation's newfound rights, the Continental Congress thought it important to not only mention trial by jury, but also to explain that this jury trial right was public, expressive, and local. The very key to the "great right" was the twelve "unexceptionable countrymen and peers" of the vicinage, which was understood to be the local community. ${ }^{224}$ Although the right certainly had an effect on the defendant, the heart of it was focused on the communitarian role of punishment.

\section{Constitutional Codification of the Jury Trial}

The understanding of the jury trial right as the local community's right was in full evidence during the drafting and ratification of the Constitution. Early versions of the right to a jury trial in the document required criminal cases to follow the "accustomed requisites"- the historical jury trial customs practiced both in England and in colonial America. ${ }^{225}$ It is not surprising, then, that in every discussion recorded of the debates concerning the drafting of the Constitution, jury trial as a right of the accused was rarely, if ever, mentioned.

\section{Jury Trial Rights and Constitutional Drafting}

Originally, the Committee of Detail noted simply that "Trials for Criml. Offences be in the State where the Offe was comd-by Jury." ${ }^{, 226}$ Later the Committee elaborated the right a bit, declaring that "Crimes shall be tried in the State, in which they shall be committed; and The Trial of them all Criml Offences,-except in Cases of Impeachment-shall be by Jury."227

Subsequent restatements of the jury trial right noted by James Madison and George Mason differed little from the original statement, simply amending "but when not committed within any State, then the trial shall be at such place or places as the Legislature may direct." ${ }^{, 228}$ The notes explaining this amendment stated that the object was "to provide for trial by jury of offences committed out of any State." 229

In the constitutional debates during the 1787 Federal Convention, all versions of the nascent Constitution possessed only a collective version of the jury trial right. ${ }^{230}$

223. Continental Cong., Address to the Inhabitants of Quebec (Oct. 26, 1774), reprinted in 1 JOURNALS OF THE CONTINENTAL CONGRESS 1774-1789, at 105, 107 (Worthington Chauncey Ford ed., 1904).

224. Id.

225. Kory A. Langhofer, Comment, Unaccountable at the Founding: The Originalist Case for Anonymous Juries, 115 YALE L.J. 1823, 1826 (2006).

226. 2 THE RECORDS OF THE FEDERAL CONVENTION OF 1787, at 144 (Max Farrand ed., 1937).

227. Id. at 173 .

228. Id. at 438 .

229. Id.

230. James Madison, Debates in the Federal Convention of 1787 as Reported by James Madison, reprinted in DOCUMENTS ILLUSTRATIVE OF THE FORMATION OF THE UNION OF THE 
Article XI addressed the judiciary and its various jurisdictions, but made sure to establish, in Section 4, that "The trial of all criminal offences (except in case of impeachments) shall be in the State where they shall be committed; and shall be by Jury." 231 As Stephanos Bibas notes, this original criminal jury trial right "was meant to be a right of We the People to administer justice, not . . . a right of defendants to waive." ${ }^{232}$ No individual rights were enumerated in this first draft of the Constitution.

During the discussion of Article XI in the convention, there was a general agreement that the writ of habeas corpus should be added. ${ }^{233}$ The individual right of habeas corpus, listed separately from the criminal jury trial right, was accepted as an amendment to the Constitution by a vote of seven to three. ${ }^{234}$ From the beginning, therefore, the jury trial right was essentially understood as community-based, in contradistinction to the other more individual rights of the accused.

Even when the debate opened to the potential inclusion of civil jury trials, the focus did not broaden to individual rights. On September 12, 1787, several Framers, including Hugh Williamson, Nathaniel Gorham, Eldridge Gerry, George Mason, and Roger Sherman, all championed a civil jury trial right, arguing for it as a security to the "rights of the people." ${ }^{235}$ Thus, the concerns of many of the Framers were focused on the collective nature of the jury trial right.

\section{Jury Trial Concerns in the Public Square}

So focal was the collective jury trial right that several public voices, including some prominent anti-Federalists, strongly criticized the Constitution's first iteration for inadequately protecting it. To repair this oversight, the anti-Federalists insisted on the addition of a jury trial right, one that was specifically communitarian.

First off the press in response to the draft Constitution was Centinel, who published a fire-breathing attack in the Pennsylvania press about the tyrannical despotism laid bare. Centinel honed in on the Constitution's failure to safeguard two critical rights: freedom of the press and the right to a jury trial. ${ }^{236}$ On this second theme, Centinel elaborated how this long-standing privilege "preserves in the hands of the people, that share which they ought to have in the administration of justice, and prevents the encroachments of the more powerful and wealthy citizens."237

Centinel was deeply concerned about lack of provision for the local aspect of the criminal and civil jury trial right:

Astonishing, that provision could not be made for a jury in civil controversies, of 12 men, whose verdict should be unanimous, to be taken from the vicinage; a

AMERICAN STATES, supra note 197, at 109, 479.

231. Id. at 479.

232. Bibas, supra note 5, at 196-97.

233. Madison, supra note 230 , at 627.

234. Id.

235. 2 THE RECORDS OF THE FEDERAL CONVENTION OF 1787, supra note 226, at 587-88 (statement of Sherman).

236. Centinel, Letter No. II: To the People of Pennsylvania, FreEMAN's J., Oct. 24, 1787, at

1, available at http://hdl.loc.gov/loc.rbc/bdsdcc.c0701.

237. Id. 
precaution which is omitted as to trial of crimes, which may be any where in the state within which they have been committed. ${ }^{238}$

Whether civil or criminal, Centinel understood that the jury trial right was deeply intertwined with the local community. This understanding is highlighted by Centinel's argument that even criminal jury trials were insufficiently protected, since the draft Constitution provided no specific right of vicinage, leaving the boundaries statewide. In other words, Centinel's repeated statements of concern over the local, communal nature of the jury trial right can be interpreted not only as part of the struggle between state and federal government, but also as a clear statement of the right's collective aspect.

Brutus, in his address to the citizens of New York, likewise defined the jury trial right as collective while criticizing the draft Constitution as destructive of the people's liberties. ${ }^{239}$ In his discussion of the bills of rights that state governments had provided their inhabitants, he carefully delineated the individual rights from the community jury right.

First, Brutus argued that most states provided the accused the right of confrontation, the right to not testify against himself or produce evidence against himself, the right to counsel, and the right to face his accusers, ${ }^{240}$ individual rights that the draft Constitution lacked. The next liberty mentioned was the jury trial right, and Brutus described it thus: "That it is essential to the security of life and liberty, that trial of facts be in the vicinity where they happen."241

If the jury trial right was viewed as belonging solely or even primarily to the accused, Brutus would not have distinguished it from the list of individual rights delineated in the sentence before. Instead, Brutus not only mentioned the right separately, but also linked the right to the vicinity, or the locality, of the criminal and the crime. ${ }^{242}$

Richard Henry Lee, in a letter to Edmund Randolph, further articulated both the importance of the local community in the institution of the civil jury trial and his concerns that the civil jury would be fatally compromised without mention in the Constitution:

It is the more unfortunate that this great security of human rights, the trial by jury, should be weakened in this system, as power is unnecessarily given, in the second section of the third article, to call people from their own country, in [intrastate property disputes], to be tried in a distant court where the Congress may sit ... [if this is not regulated], the people will be exposed to endless oppression. ${ }^{243}$

238. Id. (emphasis in original).

239. Letter of Brutus No. II (Nov. 1, 1787), reprinted in ThE ANTI-FEDERALIST 119-22 (Herbert J. Storing \& Murray Dry eds., 1985).

240. Id. at 119.

241. Id.

242. But see Letter of Brutus No. XIV (Feb. 28, 1788), reprinted in THE ANTI-FEDERALIST, supra note 239, at 177 ("As our law now stands, a person charged with a crime has a right to a fair and impartial trial by a jury of his country ... and their verdict is final.").

243. Letter from Richard Henry Lee to Edmund Randolph, the Governor of Va. (Oct. 16 1787), in 2 THE LetTERS OF RiCHARd HENRY LeE 454 (James Curtis Ballagh ed., De Capo Press 1970), available at http://press-pubs.uchicago.edu/founders/documents/a3_2_3s4.html. 
Lee's concern over the Constitution's failure to enumerate the community's right to the civil jury trial-the ability to "call people from their own country" to sit on the juryechoed a common theme in many anti-Federalist objections to the draft Constitution: unless the jury trial right was marked out in the Constitution as specifically local and communal, its true meaning would be lost.

Luther Martin's anonymously published essay, Genuine Information, Delivered to the Legislature of Maryland Relative to the Proceedings of the General Convention, Lately Held at Philadelphia, ${ }^{244}$ likewise demonstrated both the general concem over inadequate protection of jury trials and the belief that the jury trial right was collective. Martin railed against the lack of constitutional protection for local jury trials, arguing that "jury trials ... which have been by our several State constitutions so cautiously secured to us . . . is taken away in those very cases where of all others it is most essential for our liberty.... [A]s they could not trust State Judges, so would they not confide in State juries." 245 Martin's screed illustrated the concern over communitybased jury trial rights, as espoused in concerns for the states over the government. His understanding of the jury trial right was based entirely on the belief that the state jury was local and personal, pitching that against what he believed the Constitution required.

\section{The Vicinage Battle}

The collective nature of the jury trial right was thrown into sharp relief by the debate over the definition of vicinage, or the boundaries of the area from which the jurors would be drawn. The vicinage, which was inseparable from the community's right to judge its wrongdoers, was always a presumption in the Anglo-American legal system, ${ }^{246}$ and was envisioned as the community's or public's right. ${ }^{247}$ The local character of the jury was more than just functional, however; "it was essential to the jury's claim to represent the community."248 Indeed, common law assumed vicinage was part and parcel of the jury trial right. ${ }^{249}$

The right of vicinage was a great concern of the anti-Federalists, since the draft Constitution guaranteed a state trial but failed to secure the participation of the local community members on the jury. ${ }^{250}$ In fact, the anti-Federalist comprehension of the jury trial right was inextricable from the vicinage right.

244. Luther Martin, The Genuine Information, Delivered to the Legislature of Maryland, Relative to the Proceedings of the General Convention, Lately Held at PHILADELPHIA (Eleazer Oswald 1788).

245. Id. at 72. Martin's argument explains that the federal government was loath to trust state juries because: "the citizens of the different States would enter into their views and interests of their respective States, and therefore ought not to be trusted in determining causes in which the general government was any way interested." Id. at 73 .

246. See Henry G. Connor, The Constitutional Right to a Trial by a Jury of the Vicinage, 57

U. PA. L. REV. 197, 197-98 (1909).

247. See Engel, supra note 8, at 1674-75.

248. Id. at 1674 .

249. Id.

250. Id. at 1687. 
This understanding was reflected in a letter from the Federal Farmer to the Republicans, discussing the jury trial as a right of the people and the community: "[The people] are at all times intitled [sic] to the benefits of . . . the trial by jury in criminal and civil causes-They have a right, when charged, to a speedy trial in the vicinage ... "251 Although, in a later clause, the letter discusses the rights of the individual, it stayed true to form in viewing the jury trial right as collective. ${ }^{252}$

\section{Amending the Constitution}

The concern over the draft Constitution's failure to properly safeguard the rights of the community was articulated in many ways, including various requests to amend it. One of the earliest lists of suggested changes came from the twenty-one minority members of Pennsylvania committee, who distributed their dissent from the Constitution soon after its ratification by Pennsylvania and New Jersey. The Address and Reasons of Dissent of the Minority of the Convention of Pennsylvania to Their Constituents (the "Dissent"), which was frequently reprinted in other states, focused directly on the jury trial right. After freedom of the press, second on the list of the Pennsylvania minority's amendments was the civil "right to trial by jury,"253 illustrating a concern over community decision making in non-criminal cases.

Third on the Pennsylvania minority's list were a number of individual rights not included in the draft Constitution, including the right to counsel, the right to confrontation, and the right to produce witnesses. ${ }^{254}$ Included in this list was also the criminal jury trial right. This version of the criminal jury trial right provided that a man had a right to "a speedy trial by an impartial jury of his vicinage, without whose unanimous consent, he cannot be found guilty ... and that no man be deprived of his liberty, except by the law of the land or the judgment of his peers."25s Thus the Pennsylvania minority seemingly shifted some part of the right to the individual accused, ${ }^{256}$ while still retaining the rest of the criminal jury trial right for the community's benefit. 257

251. Letter of The Federal Farmer No. VI (Dec. 25, 1787), reprinted in ADDITIONAL NUMBER OF LETTERS FROM THE FEDERAL. FARMER TO THE REPUBLICAN; LEADING TO A FAIR EXAMINATION OF tHe System OF Government, Proposed by the Late Convention; to SEVERal EsSential

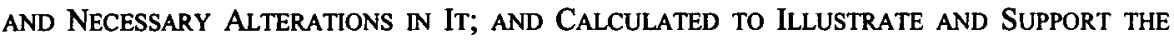
Principles and Posttions Laid Down IN THE Preceding LetTers 45, 53 (Thomas Greenleaf 1788).

252. Id.

253. The Address and Reasons of the Dissent of the Minority of the Convention of Pennsylvania to Their Constituents, PA. PACKET \& DAILY ADVERTISER, Dec. 18, 1787, reprinted in THE ANTI-FEDERALIST, supra note 239 at 201; see also SAUL CORNELL, THE OTHER FOUNDERS: ANTT-FEDERALISM AND THE DISSENTING TRADITION IN AMERICA, 1788-1828, at 32 (1999).

254. The Address and Reasons of Dissent of the Minority of the Convention of Pennsylvania to Their Constituents, supra note 253, at 207.

255. Id.

256. Id. (" $[\mathrm{A}]$ man has a right ... to a speedy trial.").

257. Id. ("[Requiring a] trial by an impartial jury of his vicinage [and] unanimous consent... or the judgment of his peers [to deprive a man of his liberty]."). 
At first glance, this division of the criminal jury trial right into both individual and collective rights seems to differ significantly from the interpretation normally used at this time. Reading further into the document, however, helps significantly clarify matters.

After expressing concerns that in the Constitution's current form, even the criminal jury trial right could be eradicated, ${ }^{258}$ the Dissent bemoaned the lack of local specifications in the draft Constitution. Specifically, the Dissent noted that "the benefit of jury trial, in cases of a criminal nature, which cannot be evaded, will be rendered of little value, by calling the accused to answer far from home; there being no provision that the trial be by a jury of the neighbourhood or country."259

In other words, even in a bill that looked like it provided an individual criminal jury trial right, the primary understanding of that right was still focused on the community. The county or neighborhood jury-its regional, personal nature-remained. For the Pennsylvania Dissent, this was the essence of the criminal jury trial. Without the local, collective participation, there could be no individual right at all.

Following suit, New York Governor George Clinton wrote a letter containing amendments to the Federal Constitution proposed by the New York State Convention, copies of which were distributed to Rhode Island, among other states. ${ }^{260}$ Clinton's letter discussed the necessary protections for the right to jury trial in substantial detail, arguing that all crimes must have a trial which was "speedy, public and by an impartial jury of the county where the crime was committed, and that no person can be found guilty without the unanimous consent of such jury."261

The right to a jury trial was carefully delineated from the rights of the accused, ${ }^{262}$ evincing a distinction between the two. Moreover, the rights of the accused were only mentioned after the right of the county, or local community, to judge criminal offenders was specified. ${ }^{263}$

The collective understanding of the jury trial right recurred in the Federal Farmer's letters. In Letter XV, Federal Farmer lamented the lack of a civil jury trial right, and explained in no uncertain terms how the right of the people (as opposed to judges) to give their general verdict in all cases was intrinsic to the nation's freedom: "Juries are constantly and frequently drawn from the body of the people, and freemen of the

258. Id. at 216 . This could be done by requesting fines instead of punishment (therefore converting it into a civil trial). See id.

259. Id.

260. See Letter from George Clinton, Governor of N.Y., to the R.I. General Assembly (July 26, 1788), available at http://memory.loc.gov/cgi-bin/query/r?ammem/bdsbib: @ field(NUMBER+@od1(bdsdcc+c1801)).

261. Id. at 2 .

262. The letter stated that:

[T] he accused ought to be informed of the cause and nature of his accusation, to be confronted with his accusers and the witnesses against him, to have the means of producing his witnesses and the assistance of council for his defence, and should not be compelled to give evidence against himself.

Id.

263. See id. Specifically, for crimes committed outside any United States counties, or in counties in a state of "general insurrection," the trial "should be as near as conveniently may be to that county in which the crime may have been committed." Id. 
country; and by holding the jury's right to return a general verdict in all cases sacred, we secure to the people at large, their just and rightful controul [sic] in the judicial department." 264

Later in the same letter, the author underlines how the public, expressive nature of the jury trial is critical to its workings: "The body of the people, principally, bear the burdens of the community; they of right ought to have a controul [sic] in its important concerns .... . [T] he jury trial brings with it an open and public discussion of all causes, and excludes secret and arbitrary proceedings." 265 This grounding in the community was intrinsic to the jury trial right.

\section{Debating Ratification}

This battle over the jury trial right spilled out into the various states as they considered ratification. Prominent anti-Federalists such as Elbridge Gerry objected to the draft Constitution due to its insufficient restraints of governmental power and limited guarantees of personal liberties. The jury trial right, civil and criminal, was at once a part of that general concern, and an issue all to itself. As such, the debates over its articulation in the Constitution raged fiercely.

In the ratifying debates of the Massachusetts Convention, anti-Federalist Abraham Holmes argued against ratifying the draft Constitution because of its failure to define the word "jury." 266 According to Holmes, the understanding of what a jury comprised needed to be specifically articulated to properly preserve the right in criminal trials-a job that the Constitution failed to do.

Holmes found the Constitution's provisions for federal criminal trial so troubling precisely because it failed to preserve the community's sacred right; the accused might be tried by strangers, rather than a jury of his peers, who, lacking the "local situation," might not have "an opportunity to form a judgment of the character of the person charged with the crime, and also to judge of the credibility of the witnesses." ${ }^{267}$ This could result in not only the accused being unable to properly prepare for his defense, but also in a jury that would be "interested in his conviction." ${ }^{\text {"268 }}$ Stated differently, Holmes was concerned that the draft Constitution's jury would not be composed of the local community, and the jury trial right would not be used for its primary purposehanding down the judgment of the defendant's peers and neighbors.

264. Letter of The Federal Farmer No. XV (Jan. 18, 1788), reprinted in ADDITIONAL

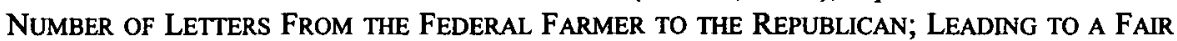
Examination of the System of Government, Proposed by the Late Convention; to SEVERAL ESSENTIAL AND NECESSARY ALTERATIONS IN IT; AND CALCULATED TO ILLUSTRATE AND SUPPORT THE PRINCIPLES AND POSITIONS LAID DOWN IN THE PRECEDING LETTERS, supra note 251, at $130,138$.

265. Id.

266. Debates in the Convention of the Commonwealth of Massachusetts on the Adoption of The Federal Constitution, in 2 The Debates In THE Several State Conventions, ON THE ADOPTION OF THE FEDERAL CONSTITUTION, AS RECOMMENDED BY THE GENERAL CONVENTION AT PHILADELPHIA, IN 1787, at 109-12 (Jonathan Elliot ed., 2d ed. 1836), available at http://lcweb2.loc.gov/ammem/amlaw/lwed.html (statement of Abraham Holmes).

267. Id. at 110 (emphasis in original).

268. Id. 
Again, there was minimal discussion of the jury trial right as an individual right. ${ }^{269}$ This was in marked contrast to Holmes's articulation of the traditional individual rights arising during the "mode of trial," including the right to counsel, the right of confrontation, the right against self-incrimination, and the right of cross examination. ${ }^{270}$

Even the Federalists agreed on the basic notion of the collective jury trial right. In the Federalist No. 83, Alexander Hamilton discussed the Constitution's lack of provision for civil jury trial rights, and comparing it to the criminal jury trial right, articulated the latter almost entirely in terms of the community: "[T]he security of liberty is materially concerned only in the trial by jury of criminal cases ... [E]ven in far the greatest proportion of civil cases, and those in which the great body of the community is interested, that mode of trial will remain in its full force . . . .271 Hamilton thus specifically linked the interest of the community with the right to the jury trial, whether criminal or civil.

James Madison defined the jury trial right as a right depending primarily on the need of the local community to proclaim judgment on the alleged wrongdoing. Responding to the specific criticism that the Constitution did not specify that a jury's vicinage, Madison's argument reinforced the idea that local decision makers were crucial to the jury trial process, despite his contention that vicinage rights must be subject to the will of Congress:

It was objected, yesterday, that there was no provision for a jury from the vicinage .... It might so happen that a trial would be impracticable in the country. Suppose a rebellion in a whole district; would it not be impossible to get a jury? The trial by jury is held as sacred in England as in America. ... It is a misfortune in any case that this trial should be departed from; yet in some cases it is necessary. It must be, therefore, left to the discretion of the legislature to modify it according to circumstances. ${ }^{272}$

Madison's concern focused mostly on the inability to get a local jury in certain emergency situations. Notably, though, his understanding of the jury trial right was remarkably similar to that of the anti-Federalists-not only was the trial by jury absolutely critical to the creation of the new American nation, but it was also deeply enmeshed in the right of the community to judge the offense.

Patrick Henry's response to Madison is illuminating in its fierce defense of the jury trial as both the backbone of American democracy as well as the great tool of the local community. Infuriated with Madison's explanations that the jury trial was fairly protected in the Constitution, Henry excoriated Madison's defense of the newly created

269. However, Holmes did seem to grant some aspect of the jury trial right to the accused. See id.

270. Id. at 110-11.

271. ThE FEDERALIST No. 83, at 432 (Alexander Hamilton) (Garry Wills ed., 1982) (emphasis added).

272. The Debates in the Convention of the Commonwealth of Virginia on the Adoption of The Federal Constitution, in 3 THE DeBates IN THE SEVERAL STATE CONVENTIONS, ON THE ADOPTION OF THE FEDERAL CONSTITUTION, AS RECOMMENDED BY THE GENERAL CONVENTION AT PhILADELPHIA, IN 1787, supra note 266, at 537 (emphasis in original) (statement of James Madison). 
rights of appeal from a jury verdict, claiming it would upset the rule of law as it was then known.

Particularly incensed about what he saw as the Constitution's insufficient jury trial protection, Henry underlined the local, communal aspects of the trial by jury:

Some gentlemen have observed that the word jury implies a jury of the vicinage .... By the bill of rights of England, a subject has a right to a trial by his peers. What is meant by his peers? Those who reside near him, his neighbors, and who are well acquainted with his character and situation in life. ${ }^{273}$

Henry's statement illustrated both the general understanding of the meaning of the jury trial right as well as the great fear of any infringements upon it.

The accepted definition of "jury" was a local jury. The trial of one's peers was defined as those people who "reside near" the accused-literally, his neighborhood community, those people who know his character and situation. Henry took pains to note that the very essence of the jury trial right was to allow those familiar with the defendant to adjudicate his guilt or innocence. As such, the constitutional failure to specify vicinage was unacceptable. The right to a jury trial was only properly exercised when the jury was comprised of the defendant's intimates, those members of the local community.

Henry's concern about the non-local nature of the federal jury was most tellingly articulated when he compared the federal jury trial right to that of the state of Virginia. Returning to the definition of vicinage, Henry rejected the constitutional understanding of the term, supposedly inherent in the word "jury," as entirely too vague. ${ }^{274}$

Henry's comparison of the federal jury trial right to the Virginia jury trial right is important because the Federal Constitution did differ so significantly, in that respect, from the various state constitutions. In Henry's eyes, as well as his like-minded compatriots, ${ }^{275}$ the federal government's disregard of the importance of the jury trial right and insufficient protection of it was not just indicative of the newly reduced importance of the people but also showed a disregard for the institution of the community itself. This was a concern distinct from the battle over state and federal powers.

As Henry warned in his earlier debate with Madison, "The verdict of an impartial jury will be reversed by judges unacquainted with the circumstances." ${ }^{276}$ In other words, the debate over the jury trial right was not just state versus federal control, or the people versus the government, but the community's will versus the will of the outsider.

New York's Ratification Convention, which took place on July 26, 1788, demanded that a number of amendments be added to the draft Constitution in order to secure that

273. Id. at 579 (emphasis in original) (statement of Patrick Henry).

274. See id. at 578-79 (statement of Patrick Henry).

275. Compatriots like William Grayson warned that Article IX, Section 4's lack of specificity regarding vicinage undermined its true meaning, which he defined as "that a man shall be tried by his neighbors." Id. at 569 (statement of William Grayson).

276. Patrick Henry, Address to the Delegates (June 20, 1788), in 3 ThE DeBATES IN THE Several State Conventions, on the adoption of the Federal Constitution, as RECOMMENDED BY THE GENERAL CONVENTION AT PHILADELPHIA, IN 1787, supra note 266, at 540. 
state's vote. ${ }^{277}$ Tellingly, in the list of proposed amendments, the convention distinguished the collective jury trial right from the bundle of rights commonly ascribed to the accused.

After articulating the right of habeas corpus, banning unreasonable bail and cruel and unusual punishment, and detailing the need for a grand jury process as a preliminary to all criminal trials, ${ }^{278}$ the New York amendments specified that "such trial should be speedy, public, and by an impartial Jury of the Country where the Crime was Committed; and that no person can be found Guilty without the unanimous consent of such Jury."279

Contrast the above description of the jury trial right with New York's enumeration of an offender's rights, which included confrontation, production of witnesses, right to counsel, and self-incrimination. ${ }^{280}$ All of these rights pertain and belong to the accused, from the right of confrontation to the right to counsel to the right against selfincrimination.

If the right to a jury trial was viewed as belonging to the accused, then logically it would have been placed in the list of offender's rights. The separation of the jury trial right from the individual rights in the New York Ratification Convention provides further evidence that the former was primarily collective.

The amendments suggested by Maryland's Ratifying Committee reflected much the same understanding of the jury trial right. Second on their list of amendments was the criminal jury trial right, with vicinage assigned to the state, and third was the establishment of a civil jury right. ${ }^{281}$ Neither amendment mentioned the accused. ${ }^{282}$ Only in the proposed Fifth Amendment, discussing civil "trespasses," did an individual's right to a jury trial emerge. ${ }^{283}$

The issue of the collective jury trial right was so paramount that the Maryland committee, after the first seven amendments, placed a paragraph explaining that their first object was "to secure the trial by jury in all cases, the boasted birth-right of Englishmen, and their decendants [sic], and the palladium of civil liberty."284

In all of these amendments, the primary concern was, in the words of Melancton Smith, "How was the will of the community to be expressed?" ${ }^{285}$ Community rights were the mainstay of the complaints about the draft Constitution, both specifically-

277. See New York Ratification Convention (July 26, 1788), reprinted in FouNDING AMERICA: DOCUMENTS FROM THE REVOLUTION TO THE BILL OF RIGHTS 600-604 (Jack N. Rakove ed., 2006) [hereinafter FoUNDING AMERICA].

278. Id. at 602 .

279. Id.

280. Id.

281. Address to the People of Maryland (April 21,1788), reprinted in 2 THE DEBATES IN THE Several State Conventions, on the adoption of the Federal Constitution, as RECOMMENDED BY THE GeNERAL CONVENTION AT PHILADELPHIA, IN 1787, supra note 266, at 547.

282. See id. at 1 .

283. See id. at 2. The proposed Fifth Amendment secured an individual's right to a jury trial as a right of the property owner, not of the trespasser.

284. Id. at 2.

285. Melancton Smith, Address to the Convention (June 20,1788), reprinted in THE Essential Federalist and Anti-Federalist Papers 42, 46 (David Wootton ed., 2003),

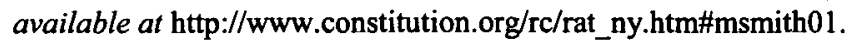


regarding the jury trial right—and more generally, regarding the people's representation in the new republic. ${ }^{286}$

Roger Sherman's draft amendments to the Constitution, written in the same narrow time period, are also instructive. Third on his list of amendments was the jury trial right, which he described as "[n]o person shall be ... convicted but by the unanimous verdict of a Petit Jury of good and lawful men Freeholders of the vicinage or district where the trial shall be had."287

In this document, Sherman does not even use "rights" language; instead, he simply states that an accused can only be convicted by his local community. ${ }^{288}$ This can be contrasted with his second proposed amendment, which discusses in detail the people's "natural rights," including rights of conscience, acquiring property, pursuing happiness, free expression, peaceful assembly, and governmental redressing of grievances. ${ }^{289}$ This separation of the individual rights from the collective jury trial right points to a different classification than that of the modern day.

\section{Jury Trials in the Bill of Rights}

By the time the Constitution had been ratified by the necessary nine states, several bodies had drafted amendments to be inserted in the body of the Constitution, but no proposal had been made for a declaration of rights. ${ }^{290}$ After a number of states provided their drafts of potential amendments, James Madison proposed a bill of rights to the House on June $8,1789 .{ }^{291}$ Madison's amendments contained a variety of protections for the criminal jury trial right.

Madison's proposed changes to the structural provisions of Article III, Section 2, Clause 3 provided support to the community jury right. In his speech introducing the amendments in the House of Representatives, Madison proposed striking Article III, Section 2 entirely, and inserting instead: "The trial of all crimes . . . shall be by an impartial jury of freeholders of the vicinage, with the requisite of unanimity for conviction, of the right of challenge, and other accustomed requisites . . ."292

This alteration reflected the deep concem that many had regarding the lack of a specific vicinage provision. Madison's revision of the criminal jury trial right signaled the importance of the local citizenry's participation in the jury trial process to the creators of the new American government, as well as recognition that the common meaning of jury trial right centered on the community.

The discussion in the House over amending the Constitution reflected this as well. Granted, the House did agree to a provision that looks to modern eyes like an individual right. Even this language, however, indicates a strong collective underpinning. The House amendments provided that the accused "shall enjoy" the right

286. See id.

287. Roger Sherman, Draft Amendments (July 21-28, 1789), reprinted in FouNDING AMERICA, supra note 277, at 627.

288. See id.

289. Id.

290. See Framing the Bill of Rights, FouNDING AMERICA, supra note 277, at 611-12.

291. See James Madison, Speech Introducing Amendments in the House of Representatives (June 8, 1789), reprinted in FOUNDING AMERICA, supra note 277, at 613, 618.

292. Id. 
to a "speedy and public trial.", 293 Therefore, whatever individual right the accused possessed was also subject to a public hearing, in the presence of the community. This public aspect is not necessarily to the benefit of the accused-after all, a defendant might prefer to have his trial hidden from prying eyes, the better to pay off the participants. Importantly, the accused may only "enjoy" this privilege, which seems to imply something less than complete possession.

Contrast this to Article 10, which stated that the "trial of all crimes ... shall be by an impartial Jury of the Vicinage, with the requisite of unanimity for conviction, the right of challenges, and other accostomed requisites . . ."294 The use of the word "vicinage" was purposeful and used to specifically indicate the district or county, a legal meaning that was generally understood at the time. ${ }^{295}$

Moreover, there was no hesitancy in the language of the amendment. A criminal trial "shall be" heard by an impartial jury comprised of the local community-phrasing much more powerful than the weaker "shall enjoy" language provided to the accused.

The Senate, however, would not accept the "local" aspect of the criminal jury right, despite Madison's best efforts. ${ }^{296}$ Article X of the House amendments, concerning vicinage, was acknowledged only by the reference to "the State and district wherein the crime shall have been committed," which was much less robust than what the House had originally provided. ${ }^{297}$

After the proposed amendments were tossed from the House to the Senate to the House again, the ultimate text of what became the Sixth Amendment listed the collective jury trial right alongside the traditional rights of the accused.

\section{Framing the Sixth Amendment}

Despite the jury trial right's placement in the Sixth Amendment, however, there is no evidence to show that its meaning suddenly switched from a collective right to an individual right. The Sixth Amendment states that "the accused shall enjoy the right to a speedy and public trial, by an impartial jury of the State and district wherein the crime shall have been committed, which district shall have been previously ascertained by law." 298

The phrasing of the Sixth Amendment deserves careful scrutiny and analysis. In its first clause, the Amendment grants the accused the right to a speedy and public trial, a fairly simple and straightforward proposition. ${ }^{299} \mathrm{~A}$ defendant is entitled to a prompt, free, and open trial, not one hidden behind closed doors or conducted years later.

293. House of Representatives, Amendments to the Constitution, 1 ANNALS OF CoNG. 756 (Joseph Gales ed., 1834).

294. Amendments Proposed by the House of Representatives (Aug. 24, 1789), reprinted in FOUNDING AMERICA, supra note 277, at 629, 631 .

295. See House of Representatives, Amendments to the Constitution, 1 ANNALS OF Cong. 760 (Joseph Gales ed., 1834).

296. See Stanton D. Krauss, The Original Understanding of the Seventh Amendment Right to Jury Trial, 33 U. Rich. L. REv. 407, 426 (1999) (reviewing AKHIL REED AMAR, THE BILL OF RighTS: CREATION AND RECONSTRUCTION (1998)).

297. Amendments Proposed by the House of Representatives, supra note 294, at 631.

298. U.S. CONST. amend. VI.

299. Id. cl. 1. 
The second clause of the Sixth Amendment, however, is critical. This clause, separated out by a comma, denotes the collective nature of the jury trial right: that is, that the jury must not only be "impartial," but must be comprised from the "State and district wherein the crime shall have been committed." ${ }^{300}$ In other words, the aspect of the trial concerning the jury is local and communal, belonging to those men who reside in the immediate district. The accused has a right to a trial that is speedy and public, but the jury trial piece is a right reserved to the community.

If the authors of the Bill of Rights had wished to grant the accused the jury trial right as well, then surely the amendment would have looked more like this: "the accused shall enjoy the right to a speedy and public JURY trial, drawn from the State and district wherein the crime shall have been committed." The fact that the second passage of the Sixth Amendment separates out the jury aspect of a defendant's trial indicates that this right was separate from the rest of the individual rights listed.

Ultimately, what looks to our eyes like a purely individual right would have been interpreted quite differently when the Bill of Rights was drafted. Popular understanding of the jury trial right would have unquestionably seen it as a right of the community, no matter where or how it was inserted into the Constitution. ${ }^{301}$ Unlike the contested definition of vicinage, the jury trial right was solidly interpreted as belonging to the local community, so much so that its placement within the bundle of defendant's rights would not have changed its common public meaning. It was only the passage of time and habits of careless interpretation that altered the original understanding of the right to trial by jury.

Why, then, was this collective jury trial right placed in a list of individual rights? First, a study of the various draft amendments shows that many of the rights which made it into the Bill of Rights were truncated, shortened, and/or combined with other rights for brevity's sake. The Sixth Amendment catalogued all the rights attached to criminal indictment and trial; it is possible that given the popular understanding of the jury trial right, adding the right to the rest of the trial rights, whether individual or collective, was done as a measure of expediency.

Second, it is possible that the jury trial right was added to the list of the individual rights in the Sixth Amendment as a way to quiet the fears of those (extremely vocal) Framers who claimed that the new system of government was designed to trample on individual rights. As Akhil Amar has documented, the Anti-Federalists' distrust of the federal legislature's ability to truly represent the people resulted in their strong focus on the average person's right to serve as a juror. ${ }^{302}$ The Anti-Federalists were disturbed at the application of national laws onto the local communities, unadulterated by the particular needs of that area. ${ }^{303}$ Thus, adding the jury trial right to the list of individual rights protected in the Sixth Amendment was likely a gesture to help quiet AntiFederalist unrest.

Amar rightly observes that the jury trial right was never "simply and always an individual right but also an institution of localism and popular sovereignty. ${ }^{, 304}$ But the criminal jury trial right was greater than this. As understood in the colonial and

300. Id. $\mathrm{cl} .2$.

301. See supra Parts III.A-B.

302. See AMAR, supra note 8 , at 11.

303. See id.

304. Id. at 106. 
Revolutionary era, the jury trial right was envisioned primarily as a local, communitybased right with little thought given to the rights of the defendant.

As Amar notes, the actions of the American jury "were expected to be informed by community values" 305 - thereby not only allowing the community the specific right of a public trial, but also ensuring that the populace could retain their role as local arbiters of punishment. Additionally, the ability to participate in a criminal jury trial provided representation and voice on a variety of different levels.

Finally, the right of the accused to a "public" trial was also a nod to the rights of the local community - the public, expressive aspect of the right was a way that the local community was formalized into the Constitution. The right to a jury trial, then, had both expressive and moral significance, allowing the average citizen a way to contribute to the politics of the local as well as a greater national polity simultaneously.

Accordingly, the right to a jury trial, despite its location in the collection of defendant's rights articulated in the Sixth Amendment, was never anything but an integral right of the community. This new historical understanding requires us to reconsider how easily we allow the collective jury trial right to be ameliorated in our current world of bench trials, plea bargaining, and guilty pleas.

\section{Erosion and Decline}

The fidelity to the community's role in the right to a jury trial began to waver as the eighteenth century turned into the nineteenth. Jury trials came increasingly under judicial control. ${ }^{306}$ Juries lost their right to decide the law, and their role in deciding the facts became increasingly restricted.

Nonetheless, juries were still performing their typical mediating functions well into the latter parts of the nineteenth century. ${ }^{307}$ In his masterwork Democracy in America, ${ }^{308}$ Alexis de Tocqueville marveled at the primacy of the jury as an essential aspect of America's democratic experiment. Recognizing that the jury had great influence on "the destinies of society at large,"309 Tocqueville liked the American jury trial because it placed "the real direction of society in the hands of the governed, or of a portion of the governed, and not in that of the government.." ${ }^{, 310}$ Loosely decoded, Tocqueville admired how the jury trial gave control to the people.

Tocqueville's discussion of the civil jury trial, however, is where he truly developed the special role of the jury as a community and representative body. Discussing the jury trial as a tool of the people, Tocqueville contended that "the jury contributes powerfully to form the judgment and to increase the natural intelligence of a people;... . [i]t may be regarded as a gratuitous public school.",311

Tocqueville's appreciation of the jury trial was entirely predicated on the benefits that resounded to the community. As he noted, although he was unsure whether the jury

305. Id. at $88-89$.

306. See Pole, supra note 89 , at 134.

307. See id.

308. 1 AleXIS de ToCQUeVILle, Democracy IN AMERICA (Francis Bowen trans., Alfred A. Knopf, Inc. 4th prtg. 1948) (1835).

309. Id. at 282.

310. Id.

311. Id. at 285 . 
was a useful tool to those being judged, he was "certain it is highly beneficial to those who judge them." 312 Tocqueville was greatly impressed with the jury's ability to be "the voice of the community represented by that institution."

The idea that jury trial rights meant community rights held sway until at least the mid-nineteenth century. Even after this time, state supreme courts continued to hold that trial-less procedures, such as guilty pleas, were unconstitutional because they took away the community's right to adjudicate the offender's guilt and punishment. ${ }^{314}$ For example, in 1865 the Tennessee Supreme Court reversed a guilty plea with the admonishment that a public trial could not "be defeated by any deceit or device whatever." 315

As the nineteenth century hastened towards the twentieth, however, the role of the jury trial began to diminish. The climbing number of felonies in both the state and federal arenas, combined with the increasing length of trials and complexity of evidentiary rules, has resulted in many fewer jury trials and a great many more guilty pleas. The twenty-first century has only exacerbated this trend, with approximately ninety-five percent of all criminal indictments adjudicated through guilty pleas. ${ }^{316}$

Our current diminishment of the jury's role, however, does not change the original meaning and practice of the jury trial right. Ultimately, a textual-historical analysis of original sources from the Colonial era through the Constitutional ratification period strongly indicates that the right to a jury trial was collective. The jury trial right, particularly the criminal jury trial right, was almost entirely predicated on validating the community's right to propound moral judgments on local citizens, and little concerned with the defendant's individual rights and liberties.

As such, this should have profound effects on how we view the criminal jury trial right today. Although twentieth-century courts have assigned the jury trial right almost exclusively to defendants, ${ }^{317}$ there is no reason why the rights of the community could not be taken into consideration as well. Accordingly, in Part IV I focus on the bench trial as a relatively simple test case for how it might look to apply a collective jury trial right to our modern-day criminal procedures.

\section{APPLYING THE COLLECTIVE JURY RIGHT TO THE BENCH TRIAL}

Returning some of the criminal jury trial right back to the community would serve a variety of purposes. First, and most obviously, restoring some measure of the jury trial right to the local community would follow the original meaning, both as understood in the eighteenth century and as formalized into the Bill of Rights. As I have discussed

312. Id.

313. Id. at 286.

314. See Adam H. Kurland, Providing a Federal Criminal Defendant with a Unilateral Right to a Bench Trial: A Renewed Call to Amend Federal Rule of Criminal Procedure 23(a), 26 U.C. DAVIS L. REV 309, 320 (1993).

315. DAVID J. BODENHAMER, FAIR TRIAL: RIGHTS OF THE ACCUSED IN AMERICAN HISTORY 86 (1992).

316. See Ron Wright, Trial Distortion and the End of Innocence in Federal Criminal Justice, 154 U. PA. L. REV. 79, 90-91 (2005).

317. See Patton v. United States, 281 U.S. 276 (1930) (assigning jury trial right to defendant). 
above, since the Supreme Court has grounded much of its sentencing jurisprudence on the historical rights of the community, the original meaning of the jury trial right has renewed import, particularly in the area of sentencing.

One way to exercise the collective jury trial right today is to eliminate bench trials. Bench trials occupy an odd middle ground in the realm of the jury trial right. Neither a full waiver of the jury trial, such as a guilty plea, nor a carefully regulated criminal procedure such as a full jury trial, the bench trial is a strange animal, neither fish nor fowl. Accordingly, it deserves reevaluation under a theory of community jury rights.

In discussing bench trials, the Supreme Court itself noted that jury trial waivers were "isolated instances" and "clear departures from the common law." 318 Until 1827, the English common law gave no other option but jury trial to criminal defendants. ${ }^{319}$

Following the adoption of the Constitution, bench trials were virtually unknown. Justice Story, while sitting on a Massachusetts case, contended that trial by jury was the only permissible method of trial. ${ }^{320}$ State courts, in interpreting their own constitutions, expressed similar views. ${ }^{321}$

The Supreme Court originally expressed the view that the Constitution made jury trial the exclusive method of determining guilt in all federal criminal cases, ${ }^{322}$ although it ultimately held that a defendant "may forego" a jury trial with the express consent of the government and the court. ${ }^{323}$ Notably, "trial by jury has been established by the Constitution as the normal and ... preferable mode of disposing of issues of fact in criminal cases." 324 Additionally, courts, including the Supreme Court, have held that there is no constitutional right to a bench trial. ${ }^{325}$

It is highly unlikely that anyone in the eighteenth century ever envisioned the modern bench trial. ${ }^{326}$ In an era when guilty pleas were themselves uncommon, the idea of the accused waiving his right to a jury of his peers in favor of a judge would have been unthinkable and assumed profoundly undemocratic. Today, although bench trials are common, they are fraught with problems, both practical and constitutional.

The harms and losses created by the bench trial procedure have not been adequately addressed by the array of rights ascribed to defendants. Such concerns include the trial court's unappealable power to grant or deny bench trial requests; the fiction that a court can simultaneously inhabit the role of judge and jury; the use of bench trials as formalized plea deals where the defendant will not plead guilty but the defense counsel, prosecution, and court agree on punishment and sentence; the democratic deliberation and improved decision making that jury trials provide; and the recently

318. Singer v. United States, 380 U.S. 24, 26 (1965).

319. Id. at 28.

320. United States v. Gibert, 25 F. Cas. 1287, 1294 (C.C.D. Mass. 1834) (No. 15,204).

321. Singer, 380 U.S. at 32 n.6.

322. See Thompson v. Utah, 170 U.S. 343, 354-55 (1898).

323. Patton v. United States, 281 U.S. 276, 298 (1930). The Court noted that "the maintenance of the jury as a fact-finding body in criminal cases [has] such importance and has such a place in our traditions." Id. at 312 .

324. Singer, 380 U.S. at 35 (citation omitted) (internal quotation marks omitted).

325. See, e.g., id. at 36; Gannett Co. v. DePasquale, 443 U.S. 368, 416 (1979).

326. See Langbein, supra note 73, at 269 (noting that "In America, where the judiciary's association with the excesses of English colonial administration had led the framers to make jury trial a constitutional right, bench trial was all the harder to envision"). 
acknowledged acquittal gap between federal bench trials and federal jury trials. ${ }^{327}$ All of these concerns about bench trials, combined with the original, historical understanding of the jury trial right, give good reason to eliminate, or at least substantially reduce, the use of the procedure.

Relying on bench trials instead of using the traditional jury trial not only completely cuts off the community's right, but also eliminates any public expressive aspect of criminal justice. ${ }^{328}$ The public trial aspect of the criminal jury trial right reflects that "[w] hat transpires in the court room is public property." inescapable concomitant of trial by jury, quite unrelated to the rights of the accused." 330

Both Hale and Blackstone recognized that the public, communal nature of jury trial was essential, and each framed it not in terms of individual liberties but as part of the effectiveness of the common law trial process. ${ }^{331}$ Indeed, one of the first jury trial provisions appearing in colonial America framed it as a public, community right, not one of the accused:

That in all publick courts of justice for tryals of causes, civil or criminal, any person or persons ... may freely come into, and attend the said courts, and hear and be present, at all or any such tryals as shall be there had or passed, that justice may not be done in a corner nor in any covert manner .... ${ }^{332}$

Unquestionably, "there is a societal interest in the public trial that exists separately from, and at time in opposition to, the interests of the accused." 333

Bench trials also provide the wrong view of "justice" to the accused, making it seem as if it is entirely the state, and not the community, that is handing down punishment. By contrast, jury trials, where the representatives of the local community literally pronounce a sentence, reflect "the notion, deeply rooted in the common law, that justice must satisfy the appearance of justice." ${ }^{, 34}$ Stated differently, justice cannot be just if not handed down by the defendant's peers and fellow community members.

327. See Nancy J. King, David A. Soulé, Sara Steen \& Robert R. Weidner, When Process Affects Punishment: Differences in Sentences After Guilty Plea, Bench Trial, and Jury Trial in Five Guidelines States, 105 CoLUM. L. REV. 959, 968-69 (2005).

328. See In re Oliver, 333 U.S. 257, $270 \mathrm{n} .24$ (1948) (recognizing that the public aspects of trial provide various benefits to the community (citation omitted)); see also Gannett, 443 U.S. at 383 (noting that "great public interest in jury trials as the preferred mode of fact-finding in criminal cases" is one of the reasons why a defendant, standing alone, may not waive a jury trial (citation omitted)).

329. Craig v. Harney, 331 U.S. 367, 374 (1947).

330. Gannett, 443 U.S. at 419 (Blackmun, J., dissenting).

331. Id. at 421 .

332. Concessions and Agreements of West New Jersey, 1677, ch. XXIII, in 1 THE BILL OF RIGHTS: A DOCUMENTARY HISTORY 129 (Bernard Schwartz ed., 1971) (unusual spellings in original).

333. Gannett, 443 U.S. at 427 (Blackmun, J., dissenting).

334. Levine v. United States, 362 U.S. 610, 616 (1960) (citation omitted) (internal quotation marks omitted). 
Moreover, the handing down of justice must be done openly, in the public sphere, to maintain the "confidence of the public in judicial remedies." 335

Taking all of these bench trial irregularities into account, and keeping in mind the concern that a juryless trial would have originally created, it may be time to consider eliminating the bench trial altogether-or at least severely curtailing the bench trial to a very limited set of circumstances. To give support to this proposition, below I sketch five major problems with bench trials as they currently stand, all of which give additional reasons to eliminate—or sharply limit—-the criminal bench trial.

\section{A. The Power Shift to the Trial Judge}

One common complaint against the bench trial is that it gives too much power to the trial court to decide whether the offender is permitted to have the bench trial in the first place. ${ }^{336}$ The individual judge, and sometimes the prosecution as well, must approve of the request. ${ }^{337}$ Considering the deep concern possessed by the Founders over any power but the local community judging an offender, it is ironic that we have now so ameliorated this collective right that it is often a single person who decides whether the accused may dispense with the jury.

The need for approval from both the judiciary and the prosecutorial arms of the law is one reason why the bench trial, as seen from the vantage of the collective jury trial right, is deeply problematic. With a bench trial, the consideration of judgment is twice removed from the imprimatur of the community-first by the agreement of the prosecution, and then by the agreement of the court.

Moreover, scholars have recently called the legal fiction that a judge can simultaneously inhabit the judicial and jury role without prejudice to the defendant into question. ${ }^{338}$ The few empirical studies that have measured the trial judge's ability to disregard evidence have shown that judges have just as much difficulty with this as jurors. ${ }^{339}$ Thus the proposition that judges can simultaneously be neutral arbiter and fact-finder-a cornerstone belief of the bench trial-rests on shaky grounds.

335. Gannett, 443 U.S. at 429 (Blackmun, J., dissenting).

336. In New York, the court must approve a defendant's request for a bench trial. N.Y. CRIM. Proc. LAW \$ 320.10(2) (McKinney 2002).

337. E.g., FED. R. CRIM. P. 23(a) (providing that a criminal defendant may elect to be tried by the court rather than a jury, but that the court must "approve" the request and the government must also "consent").

338. See Andrew J. Wistrich, Chris Guthrie \& Jeffrey J. Rachlinski, Can Judges Ignore Inadmissible Information? The Difficulty of Deliberately Disregarding, 153 U. PA. L. REV. 1251 (2005); see also Jennifer L. Mnookin, Response, Bifurcation and the Law of Evidence, $155 \mathrm{U}$. PA. L. REV. PENNUMBra 134, 136 (2006), http://www.pennumbra.com/responses/12 2006/Mnookin.pdf (questioning a judge's ability to fully set the evidentiary value of an excluded piece of evidence at zero).

339. See Wistrich et al., supra note 338, at 1323 ("Judges are indeed human; like jurors, they are often unable to "close the [v]alves of [their] attention."' (citation omitted)). 


\section{B. Bench Trials as Surreptitious Plea Deals}

Another problem with bench trials is their occasional use as unofficial, formalized plea deals. Unlike Alford pleas, ${ }^{340}$ where the defendant pleads guilty but does not admit to wrongdoing, the bench trial as unofficial guilty plea most often takes place when the accused does not wish to plead guilty, but defense counsel, the prosecution, and the trial court agree on the offender's punishment and sentence. In this situation, the accused is seemingly given "his day in court," but the end result is preordained, often without the knowledge of the actual defendant. This kind of backroom "justice" entirely violates both the defendant's and the community's right to a jury trial, and is what the right to a jury trial was intended to prevent.

\section{The Bench Trial Acquittal Gap}

Despite popular ideas about nullifying juries, it is judges who are more likely to acquit defendants than their popular counterparts. Recent empirical evidence has shown an acquittal gap between federal judges and federal juries, with courts more likely to acquit than juries. ${ }^{341}$ Although defense lawyers may applaud this development, it is worrisome that the federal judiciary acquits offenders at a statistically significant higher rate, considering that judging wrongdoers was originally marked out as a role exclusively for the local community.

Given the history of the jury trial right as a tool to express the collective imprimatur, the continued use of the federal bench trial is troubling in light of new studies. Although a case for bench trials can potentially be made in extremely complicated white-collar criminal cases, the anti-democratic ramifications of having the federal judiciary make determinations of guilt or innocence are severe.

\section{Democratic Deliberation and Improved Decision Making}

A variety of arguments supports privileging the decision-making abilities of juries over judges. Studies have shown that the decision-making processes of judges and juries are remarkably similar, ${ }^{342}$ but only juries provide the democratic deliberation so critical to the workings of our democracy.

Forty years ago, Harry Kalven noted how the jury, as a group of twelve, made better decisions than a single judge: "The distinctive strength and safeguard of the jury system is that the jury operates as a group. Whether twelve lay heads are better than one judicial head is still open to argument, but it should be recognized that twelve lay

340. See North Carolina v. Alford, 400 U.S. 25, 37 (1970) ("An individual accused of crime may voluntarily, knowingly, and understandingly consent to the imposition of a prison sentence even if he is unwilling or unable to admit his participation in the acts constituting the crime."). Alford pleas themselves have recently come under attack. See Stephanos Bibas, Harmonizing Substantive-Criminal-Law Values and Criminal Procedure: The Case of Alford and Nolo Contendere Pleas, 88 CoRNELL L. REv. 1361 (2003).

341. See Andrew D. Leipold, Why Are Federal Judges So Acquittal Prone?, 83 WASH. U. L.Q. 151 (2005).

342. See Jennifer K. Robbennolt, Evaluating Juries by Comparison to Judges: A Benchmark for Judging?, 32 FLA. ST. U. L. REV. 469, 487 (2005). 
heads are very probably better than one." 343 This is so because rigidity sometimes comes on the heels of familiarity: "experts' prior knowledge and automated thinking can cause inflexibility.",344

In addition, the very action of serving on a jury creates democratic deliberation, a process that is useful to both the individual citizen and the country as a whole. As scholars have noted, by its very inclusivity of all citizens, democratic deliberation provides "a sense of political purpose on the participants. By engaging ordinary citizens in government, deliberative democracy gives these citizens confidence about their ability to influence political decisions and thus increases their willingness to participate in politics even after the end of their jury service. ${ }^{, 345}$ Therefore, not only do juries enhance democratic decision making, but they also can provide a superior quality of decision than a judge.

\section{E. Bench Trials and Complex Criminal Cases}

The most common argument for bench trials is the alleged need for the trained minds and greater experience of judges in complex litigation. ${ }^{346}$ But does this really bear out in criminal cases?

First, although there are some complex criminal cases, the need for bench trials is comparatively less in the average criminal case. The average criminal case that goes to trial is not a patent case, nor one involving the intricacies of high technology, intensive securities law, or prescription drug side effects. Instead, the most complicated cases likely to be tried in criminal court involve either RICO or DNA evidence-areas that most jurors can comprehend and successfully apply the law. Finally, recent empirical studies have shown that even in complex business cases, juries often add value to dispute resolution-contrary to a widespread perception about their alleged inadequacies. $^{347}$

Additionally, the empirical research measuring judge versus jury comprehension of complex trials does not fall squarely in the judiciary's favor. There have been no studies that actually prove judges are better than juries in evaluating evidence, despite

343. Harry Kalven, Jr., The Dignity of the Civil Jury, 50 VA. L. REv. 1055, 1067 (1964); see also Phoebe C. Ellsworth, Are Twelve Heads Better Than One?, LAW \& CoNTEMP. ProBs., Autumn 1989, at 205.

344. Barbara A. Spellman, Response, On the Supposed Expertise of Judges in Evaluating Evidence, 156 U. PA. L. REV. PENNUMBRA 1, 8 (2007), http://www.pennumbra.com/responses/03-2007/Spellman.pdf.

345. Jenia Iontcheva, Jury Sentencing as Democratic Practice, 89 VA. L. REV. 311,342 (2003).

346. But see Louis Harris and Assocs., Inc., Judges' Opinions on Procedural Issues: A Survey of State and Federal Trial Judges Who Spend at Least Half Their Time on General Civil Cases, 69 B.U. L. REv. 731, 747 (1989) (finding that a slight majority of judges did not favor limiting jury participation even in large, complex civil litigation cases).

347. E.g., Theodore Eisenberg \& Geoffrey P. Miller, Do Juries Add Value?: Evidence from an Empirical Study of Jury Trial Waiver Clauses in Large Corporate Contracts (Comell Law School Legal Studies Reseach Paper, Paper No. 06044, 2006), available at http://papers.ssm.com/sol3/papers.cfm?abstract_id=946465. 
the general belief that judges are superior. ${ }^{348}$ As one scholar has noted, "There is no good reason to conclude that, by virtue of qualities, training, or experience, trial judges should be considered experts at weighting evidence or at fact-finding. ${ }^{, 349}$ Moreover, some scholars argue that given the uncertainty as to who is better at fact-finding, juries may be preferable to judges for policy reasons. ${ }^{350}$ Combined with the historical and democratic arguments for a jury trial, it is hard to justify the continued use of bench trials.

What would we lose if, as a measure of a fuller understanding of the jury trial right, we severely limited the use of bench trials? Obviously the criminal justice system would lose some efficiency - although not much, since the vast majority of criminal indictments end in guilty pleas. True, it would reduce the choices available to the defendant, but since the real pressure comes between pleading guilty or going to trial, ${ }^{351}$ the effect would not be so great. On the positive side of the ledger, curtailing the use of bench trials would vindicate the community's right to decide upon the offender's moral blameworthiness without taking much away from the bundle of rights we currently assign to the accused. If moderation is all, then perhaps this would be an acceptable compromise.

\section{CONCLUSION}

This new understanding of the meaning of the criminal jury trial right raises a host of questions. First, how can the jury trial right be potentially shared with the community without diminishing the rights assigned to the accused or entirely disaggregating our current system of criminal justice? Could a defendant's request for a bench trial be countered by the people's right to a jury trial? What might this mean to the fate of peremptory challenges? Finally, in a world of guilty pleas, how might a collective jury trial right be applied?

I call into question our standard understanding of the original meaning of the right to a jury trial. I also suggest that the Supreme Court's recent attempts to strengthen the jury trial right, based on the people's historical right to determine all punishment, has greater textual and historical warrant than previously supposed. Obscured by over a century of misunderstanding, it is time for the collective jury trial right to once again come into its own.

348. Cf. Frederick Schauer, On the Supposed Jury-Dependence of Evidence Law, 155 U.PA. L. REV. 165, 189 (2006) (expressing the need for more experiments on judge and jury behavior).

349. Spellman, supra note 344, at 6-7. As Spellman further explains, "trial judges can sit through hundreds of cases and never do the focused study or have the fast reliable feedback necessary for developing expertise." Id. at 7.

350. E.g., Paul H. Robinson \& Barbara A. Spellman, Sentencing Decisions: Matching the Decisionmaker to the Decision Nature, 105 CoLUM. L. REv. 1124, 1138-46 (2005).

351. Although I do not have the space to address it here, I believe that a fully recognized collective jury trial right would mandate major procedural changes in guilty pleas and plea bargaining. I hope to explore this issue, along with the others raised in the Conclusion, in my next piece. 